Article

\title{
End Point Rate Tool for QGIS (EPR4Q): Validation Using DSAS and AMBUR
}

\author{
Lucas Terres de Lima ${ }^{1, * \mathbb{D}}$, Sandra Fernández-Fernández ${ }^{2} \mathbb{D}$, Jean Marcel de Almeida Espinoza ${ }^{3}$, \\ Miguel da Guia Albuquerque ${ }^{4}$ and Cristina Bernardes ${ }^{1}$ (D)
}

1 CESAM - Centre for Environmental and Marine Studies, Department of Geoscience, University of Aveiro, Campus de Santiago, 3810-193 Aveiro, Portugal; cbernardes@ua.pt

2 CESAM-Centre for Environmental and Marine Studies, Department of Physics, University of Aveiro, Campus de Santiago, 3810-193 Aveiro, Portugal; sandrafernandez@ua.pt

3 IFSC-Federal Institute of Santa Catarina, Campus Caçador, Department of Physics, 89500-00 Caçador, Santa Catarina, Brazil; jean.espinoza@ifsc.edu.br

4 IFRS-Federal Institute of Rio Grande do Sul, Campus Rio Grande, Department of Geoprocessing, 96201-460 Rio Grande, Rio Grande do Sul, Brazil; miguel.albuquerque@riogrande.ifrs.edu.br

* Correspondence: lucasterres@ua.pt

check for

updates

Citation: Terres de Lima, L.;

Fernández-Fernández, S.; Marcel de

Almeida Espinoza, J.; da Guia

Albuquerque, M.; Bernardes, C. End

Point Rate Tool for QGIS (EPR4Q):

Validation Using DSAS and AMBUR.

ISPRS Int. J. Geo-Inf. 2021, 10, 162.

https://doi.org/10.3390/ijgi10030162

Academic Editors: Wolfgang Kainz and Paolo Dabove

Received: 3 January 2021

Accepted: 11 March 2021

Published: 12 March 2021

Publisher's Note: MDPI stays neutral with regard to jurisdictional claims in published maps and institutional affiliations.

Copyright: (c) 2021 by the authors. Licensee MDPI, Basel, Switzerland. This article is an open access article distributed under the terms and conditions of the Creative Commons Attribution (CC BY) license (https:// creativecommons.org/licenses/by/ $4.0 /)$.

\begin{abstract}
This paper presents the validation of the End Point Rate (EPR) tool for QGIS (EPR4Q), a tool built-in QGIS graphical modeler for calculating the shoreline change with the end point rate method. The EPR4Q tries to fill the gaps in user-friendly and free open-source tools for shoreline analysis in a geographic information system environment since the most used software-Digital Shoreline Analysis System (DSAS) —although being a free extension, it is created for commercial software. Additionally, the best free, open-source option to calculate EPR is called Analyzing Moving Boundaries Using R (AMBUR); since it is a robust and powerful tool, the complexity can restrict the accessibility and simple usage. The validation methodology consists of applying the EPR4Q, DSAS, and AMBUR with different types of shorelines found in nature, extracted from the US Geological Survey Open-File. The obtained results of each tool were compared with Pearson's correlation coefficient. The validation results indicate that the EPR4Q tool acquired high correlation values with DSAS and AMBUR, reaching a coefficient of 0.98 to 1.00 on linear, extensive, and nonextensive shorelines, proving that the EPR4Q tool is ready to be freely used by the academic, scientific, engineering, and coastal managers communities worldwide.
\end{abstract}

Keywords: shoreline evolution; open-source software; Geographic Information System (GIS); modeling

\section{Introduction}

Sandy beaches occupy more than a third of the global coastline [1]. Because of the high socioeconomic value of these environments, in the last 40 years, there has been a substantial increase in the coastal population [2]. The shoreline is defined straightforwardly as the line that overlaps the physical land-water boundary [3]. Shoreline data can be obtained from different sources, such as historical maps, aerial photography, Light Detection and Ranging (LIDAR) and differentialGlobal Positioning Systems (dGPS) surveys (e.g., [4-8]), video and satellite imagery (e.g., [9-16]) and recently, crowd-sourced smartphone images taken at CoastSnap stations [17]. The analysis of historical shoreline changes can combine several sources (e.g., [18-22]). Several factors influence its dynamics (e.g., waves, tides, human activities), which make them one of the most important features in coastal planning [23]. Observations of shoreline changes through the centuries are related to oscillations of sealevel and river sediment discharge, whereas those changes in the short timescale (annual to a decade) are mainly linked to hydrodynamic processes, local sediment budgets, and/or anthropogenic activities (e.g., coastal engineering works, such as nourishment operations) (e.g., [24-27]). Shoreline retreatment can cause damage to the coastal zone, such as a change 
in the beach dynamics and wear and tear on civil constructions, in addition to also resulting in socioeconomic impacts by reaching some activities inherent to the coastal zone [28]. Therefore, knowledge about the rate of shoreline changes and possible predictions in the future based on previous trends is of paramount importance for the development of coastal morphodynamic models, the budget of sediments and erosion/accretion analysis, identification of hazard areas, policy and coastal management [29].

Nowadays, there is serious growing concern about climate change problems $[30,31]$ and the expected increase of extreme events, such as bigger hurricanes and storms over coasts [32-34]. Therefore, information about shoreline changes increases the capability to manage erosion, overwash, and flooding risks and protect the population living in coastal areas [24]. These issues increase the necessity to have a quick application to detect and calculate shoreline variation rates. Currently, many studies have used change detection tools interconnected with a Geographic Information System (GIS) environment to determine changes in the shoreline position, as well as to forecast future positioning trends. There are numerous examples of methods to calculate the short- and long-term shoreline trend. These methods can be focused on shoreline distances, such as shoreline change envelope-which reports the distance between the farthest shoreline from baseline and the closest one at each transect, or net shoreline movement-, which estimates the distance between the oldest and the youngest shorelines for each transect; or they can be centered on rates, such as linear regression rate-a linear regression rate-of-change statistic; or weighted linear regression - that shows the weight towards determining a best-fit line; among others [35].

The method selected to create the tool was the End Point Rate (EPR) [36], a fast and effective technique that has the great advantage of using only two shorelines to estimate changes and/or to generate predictions. Nevertheless, the EPR has disadvantages when there are several shorelines available since this method only uses the oldest and the newest shoreline. Therefore, changes in magnitude or periodic trends may be omitted [37].

The Digital Shoreline Analysis System (DSAS) is a tool whose purpose is to calculate the change position rates for a time-series of historical shoreline vector data. Developed by the US Geological Survey, the DSAS is a free extension tool of ArcGIS Environmental Systems Research Institute (ESRI) [35] and uses the measurement baseline method to calculate the shoreline velocity or change at user-specified intervals along the shoreline [38].

One advantage of using DSAS in coastal change analysis is that it can calculate the rate of change of shoreline time-series, evaluating and resolving the nature of shoreline dynamics and changing trends [39]. Besides, DSAS has numerous applications in studies of coastal behavior and shoreline dynamics, such as historical trend analysis $[8,16,18,19,40-44]$ and expected future shoreline morphology (e.g., [45,46]).

Indeed, the DSAS allows studying the shoreline behavior worldwide. However, DSAS is not supported for current ESRI ArcGIS desktop versions (10.8) and ArcGIS Pro, and many countries and small management agencies have a low budget to work with commercial software, such as ArcGIS. Other options, such as Simple Change Analysis of Retreating and Prograding Systems (SCARPS) [47] and BeachTools [48,49], also require ArcGIS to run. To settle this, a free and open alternative of DSAS was created in R language called Analyzing Moving Boundaries Using R (AMBUR) [50]. The AMBUR package for the $\mathrm{R}$ software environment is based on another shoreline change analysis tool named SCARPS [50]. Numerous works using AMBUR can be found in the literature with examples of studies about shoreline changes at different timescales [13,51-56].

However, AMBUR has the disadvantage of the complexity to install and configure the parameters, with the necessity to edit baselines and shorelines on geographic information systems, like QGIS or ArcGIS software. These problems, combined with no user-support, are not attractive for the end-users to adopt the AMBUR as a free and open-source option for shoreline analysis in a GIS environment. Therefore, the implementation of a tool directly on QGIS [57], one of the most importantly free and open-source software for GIS, seems to be the most reasonable solution to ease the access of a fast shoreline trends analysis. 
The QGIS is a free and open-source GIS application that allows users to explore, control, evaluate, edit data, georeference images, compose and graphical export maps. QGIS supports vector data (point, line, or polygon features) and numerous formats of the raster. Furthermore, the QGIS integrates other open-source GIS packages, such as GRASS GIS, MapServer, and PostGIS [57], has a significant number of developers, and it is supported by most operating systems, including Android App for mobile phones and tablets [58]. Keeping in mind the described scenario, it is effortless to understand how useful it is the existence of a shoreline analysis tool that operates directly in QGIS software.

The first tool for QGIS to perform shoreline analysis was created by the authors in 2017 [59], a Python plugin for QGIS (not registered in the official repository) to calculate a simple shoreline movement rate $\left(\mathrm{m} \cdot \mathrm{y}^{-1}\right)$. However, this project was discontinued from a plugin to focus on creating a tool with a QGIS graphical modeler called EPR4Q that includes a future prediction of the shoreline position using the end point rate method.

The main goal of this study is to develop an alternative tool for end point rate analysis running in QGIS software. The new tool named end point rate for QGIS (EPR4Q) is subjected to a validation process by statistical comparison with well-known software, such as AMBUR and DSAS.

\section{Study Areas}

This study aims to validate the EPR4Q in different types of shorelines found in nature. To reach this purpose, it was necessary to find a shoreline database that had examples of different coastal characteristics and was also a reliable source. The excellent open available data of vectorized shorelines with errors and accuracy well reported, combined with the usage of technologies of LIDAR and Aerial photography of US Geological Survey [60-63], complete all the requirements to validate the EPR4Q with shorelines showing different shapes and orientations. The shorelines were chosen to apply and to validate the EPR4Q are located on the west and east coast of the United States of America. The coastal stretches analyzed are (i) Arlight and Concepcion in Santa Barbara County, California; (ii) Hampton in Rockingham County, New Hampshire; and (iii) Rockport, Essex County, Massachusetts (Figure 1).

California coast is exposed to Northern Pacific swell (October-May), Southern Hemisphere swell (April-October), Northwest wind-driven waves (April-October) and locally wind-driven waves (October-April). During El Niño Southern Oscillation (ENSO) winters, this coast (especially the southern region) receives more wave energy [62,64]; in fact, the 2015/2016 El Niño event caused extremely high wave energy (50\% above the historical winter mean) [22]. This micro-tidal coast presents a mixed semidiurnal tidal regime of two unequal high and low tides every day. The tidal range increases northwards [62].

New England coast is exposed to extratropical storms (commonly referred to as nor'easters), which are more frequent in winter, and tropical cyclone (hurricanes and tropical storms) events. Hurricanes can generate large waves and storm surge. For example, Hurricane Sandy in 2012 induced storm surge heights up to one meter above normal tide levels in New Hampshire [65]. This meso-tidal coast shows a semidiurnal tidal regime of two unequal high and low tides every day $[63,66]$.

These coastal states have been subjected to beach nourishment operations over the last century, the majority being in California $\left(227 \mathrm{Mm}^{3}\right)$ [67].

The sites were chosen due to the different morphological characteristics, straight and embayed coasts, orientation, and ocean and land location. These features allow testing examples of linear shorelines (Concepcion and Hampton) and indented shorelines (Arlight and Rockport), and examples with different orientations (Concepcion coast with the ocean on the west side, Rockport coast exposed to the ocean located to the north, Hampton coast with the ocean on the east side and Arlight coast with the ocean situated in the south), and extensive (extension $>1 \mathrm{~km}$, Arlight and Concepcion) and non-extensive (extension $\leq 1 \mathrm{~km}$, Hampton, and Rockport) shorelines (Table 1). 


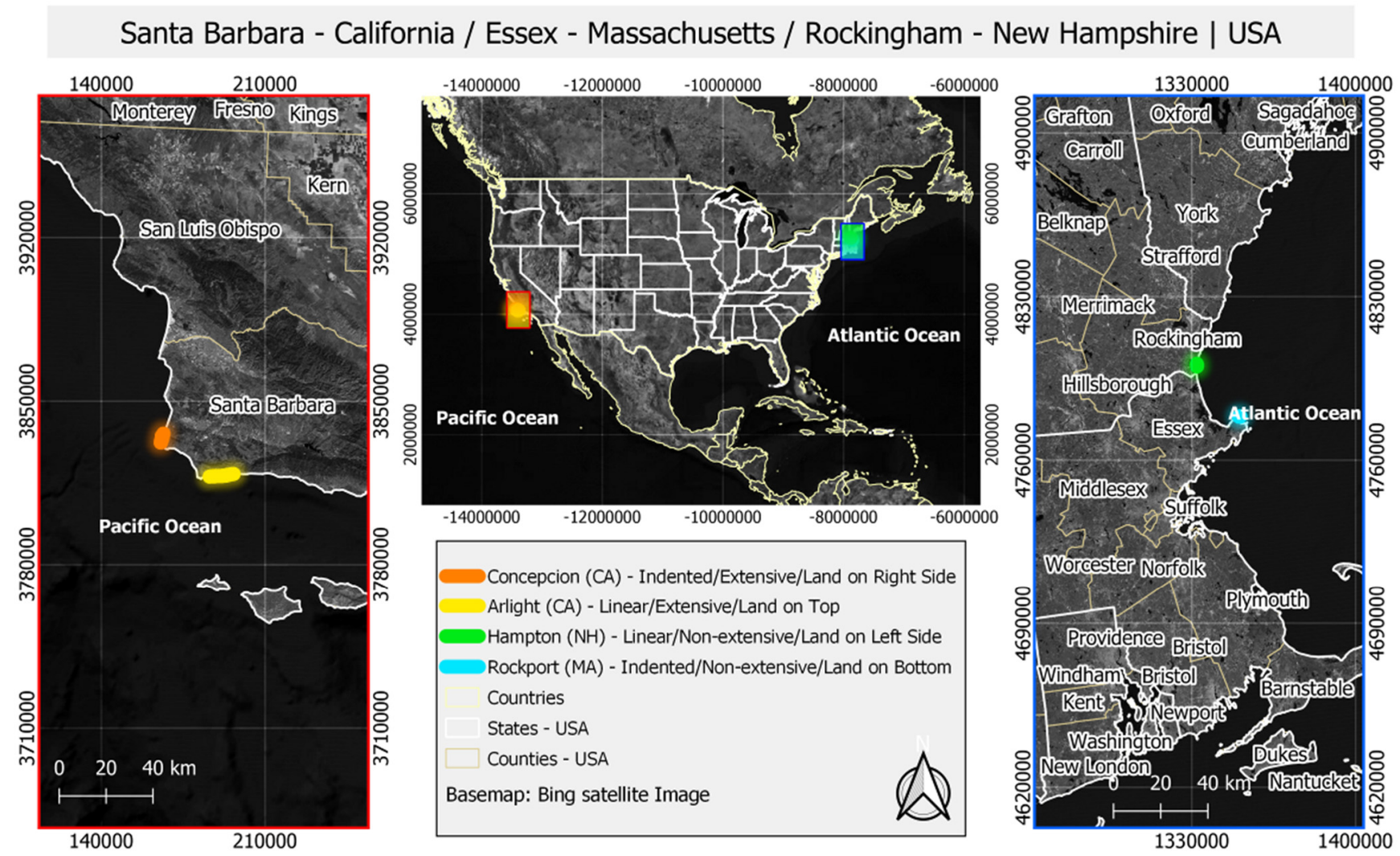

Figure 1. General location and study coastal stretches: Concepcion and Arlight shorelines, Santa Barbara (CA); Hampton shoreline, Rockingham (NH); Rockport shoreline, Essex (MA).

Table 1. General characteristics of shorelines used in the validation process.

\begin{tabular}{cccccc}
\hline Shoreline & Location & Type & Extension & Orientation & Date \\
\hline Concepcion & Santa Barbara & Linear & Extensive $(11 \mathrm{~km})$ & Ocean to the west & Mar 1976-Sep 1993 \\
Arlight & Santa Barbara & Nonlinear & Extensive $(4 \mathrm{~km})$ & Ocean to the south & Mar 1976-Nov 1993 \\
Hampton & Rockingham & Linear & Non-extensive $(1 \mathrm{~km})$ & Ocean to the east & Jul 1953-Sep 2000 \\
Rockport & Essex & Nonlinear & Non-extensive $(<1 \mathrm{~km})$ & Ocean to the north & Oct 1951-Oct 1994 \\
\hline
\end{tabular}

\section{Materials and Methods}

The EPR4Q tool calculates the distance between two shorelines by creating and measuring the length of transects between the inner and outer baseline (created by the user). Furthermore, it provides a graphical forecast of the shoreline position by using the end point rate method.

\subsection{EPR4Q Tool Creation}

The tool was created on graphical modeler QGIS desktop version 3.4-Madeira, a low-code platform (development environment for application without complex code computations) that uses the tools of processing extension. The graphical modeler allows building complex models using a simple and easy canvas interface [57]. The model workflow is organized into three main groups: transects creation, calculations, and graphical results. The transects creation group includes the inputs of the model and the core analysis that perform the geometry operations to create the transects with the distance values from baseline. The following is the calculations group that operates geometric operations and the application of the EPR equation. In the end, the graphical group is composed of the EPR forecast visualization and the results vector outputs (Figure 2). 


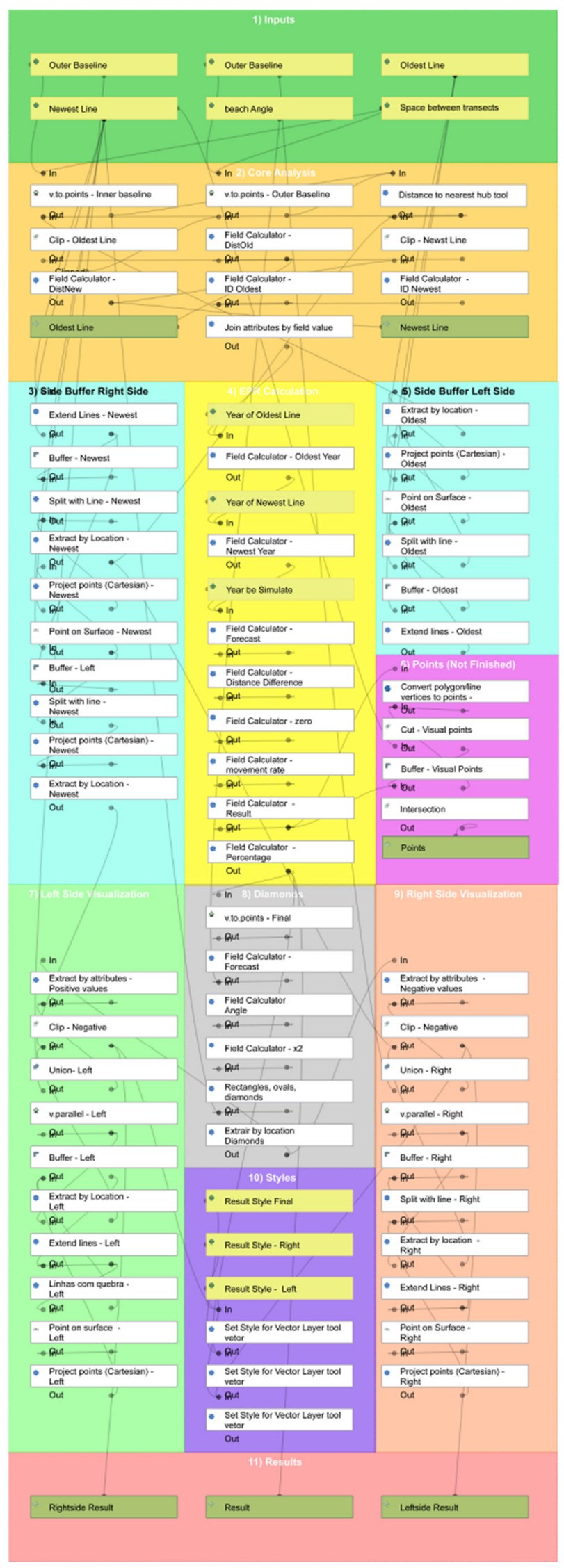

Figure 2. Graphical model of EPR4Q adapted for QGIS 3.14 since the original EPR4Q was created in QGIS 3.4. Transect creation section: dark green (1) are the inputs (shorelines and baselines); orange 
(2) is the transects creation process; calculation section: yellow (4) the application of the end point rate (EPR) equations, blue ( 3 and 5 ) is the one-side buffer creation, pink (6) is an unfinished extension; graphical result group: light green (7), gray (8) and salmon (9), and purple color (10) are the steps to the visualization of EPR forecast, and the red (11) is the model results, including the EPR forecast.

The analysis needs two shorelines to be assessed. It is also mandatory the creation of two baselines parallel to shorelines: a straight vector line on the landward (inner baseline) and seaward (outer baseline) sides of the shorelines (Figure 3a). The first step consists of transforming the baselines into points by using the v.to.points tool. The v.to.points tool creates points along input lines in a new vector [68] (Figure 3b), and this is the spacing between transects whose value is indicated by the user.

The second step consists of creating perpendicular transects between the baselines and the shorelines with the Distance to nearest hub tool (Figure 3b). The Distance to nearest hub tool calculates the distance between the start point feature and its closest end point [57]. To extract the distance value from shoreline to the baseline of each transects, it is developed an alternative for the One Side Buffer or Single-Sided Buffer tool since these tools do not result in correct geometries in the QGIS graphical modeler. The One Side Buffer or Single-Sided Buffer tool only buffers lines/polygons at a specified distance on one side of the feature [57]. In this paper, this method is called an Alternative One Side Buffer (AOSB) (Figure 3c-e). It consists of creating a polygon buffer on the vector line of shorelines and applying the algorithm Extend Lines. The algorithm extends the geometry of the line by a specified value at the start and end of the line [57], and it is applied in shoreline vectors with a value that guarantees the crossing of the buffer $(5 \mathrm{~km})$. This procedure allows the line to split the buffer into two parts with the Split with Line tool since this tool requires that the line crosses the polygon to cut it in parts. The Split with Line tool uses lines of one layer to divide lines or polygons into two or more elements [57].

The selection of only one side of the buffer is created as a point in the center of the vector line with the Point on Surface tool. This tool returns a point that is guaranteed to be on the surface of a geometry [57]. The location of this created point is shifted using the Project Points tool. This algorithm projects point geometries specifying a distance and azimuth [57]. The distance and azimuth values are automatically defined in the model (e.g., $200 \mathrm{~m}$ ) to locate the point on the surface of the buffer polygon to allow the extraction with the Extract by Location tool (Figure 3e). This algorithm creates a new vector layer that contains only matching features from the input layer [57]. The procedure gives to the model two buffer polygons from the baseline to the newest and the oldest shorelines ready to cut with the transect lines created at the beginning using the Clip tool (Figure 3e). This algorithm clips a vector layer through an additional polygon layer [57]. The tool generates two shapefiles of transect lines with the shape of the advance and retreat movement of the shoreline in the analyzed period.

The attribute table of transects includes the distance values from baseline to each shoreline (newest and oldest shoreline). The Field Calculator tool allows to perform calculations based on existing attribute values or defined functions [57], and it is used to create an identification number (ID) for each transects, and these are joined with the tool Join Attribute by Field Value tool. This algorithm creates a new vector layer with the attributes table of two vector layers together. After this, the Field Calculator tool is used to calculate the variations and the rates with the End Point Rate (EPR) method (Figure 3f). 


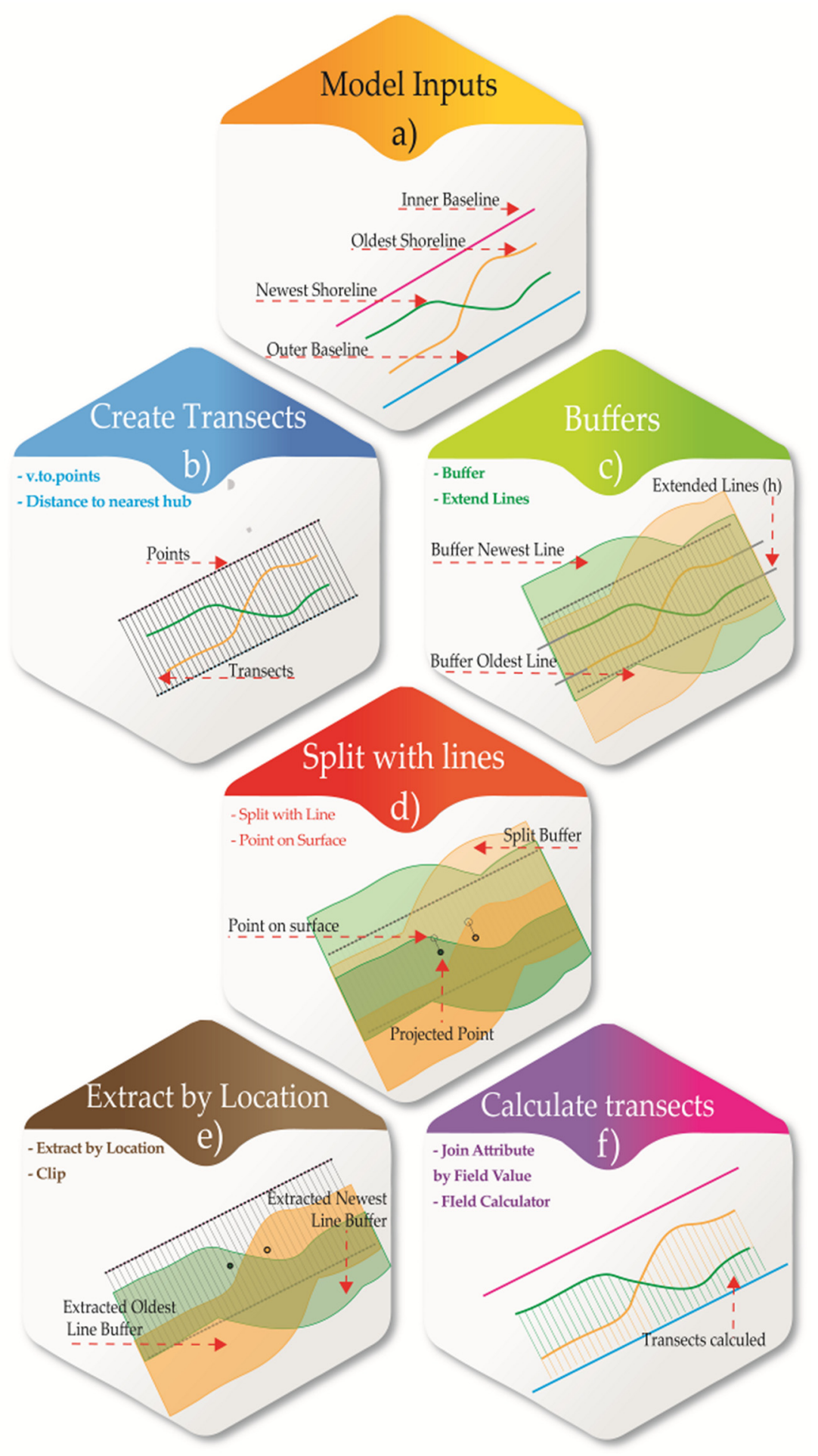

Figure 3. Graphical illustration of EPR4Q tool: (a) model inputs (oldest and newest shoreline, inner and outer baseline); (b) create transects (v.to.points tool, Distance to nearest hub tool); (c) buffers (Buffer tool, Extend Lines tool); (d) split with lines (Split with Line tool, Point on Surface tool); (e) extract by location (Extract by Location tool, Clip tool); (f) calculate transects (Join Attribute by Field Value tool, Field Calculator tool). 


\subsubsection{EPR Method}

The formulas of End Point Rate (EPR) are added in a sequence of Field Calculator tool in the Graphical Modeler (Figure 2-yellow box). The EPR method defines the shoreline position by a straight-line equation (Equation (1)):

$$
\text { shoreline position }=\text { rate } * \text { date }+ \text { intercept, }
$$

The projection of the shoreline position for a specified date is defined by the subsequent slope and Y-intercept. The EPR method uses a line selected from the two end points, the earliest and the latest positions. Using $\mathrm{Y}$ to represent the shoreline position, $\mathrm{B}$ for the intercept, $\mathrm{X}$ for the date, and $\mathrm{m}$ for the shoreline movement rate, the previous equation becomes (2):

$$
\mathrm{Y}=\mathrm{m} * \mathrm{X}+\mathrm{B},
$$

Assuming $\mathrm{N}$ samples, numbered in ascending order by date, the end point rate calculation can be rewritten (3):

$$
\mathrm{m}=\left(\mathrm{Y}_{\mathrm{N}}-\mathrm{Y}_{1}\right) /\left(\mathrm{X}_{\mathrm{N}}-\mathrm{X}_{1}\right),
$$

moreover, the EPR intercept is (4):

$$
\mathrm{B}_{\mathrm{EPR}}=\mathrm{Y}_{1-\mathrm{EPR}} * \mathrm{X}_{1}=\mathrm{Y}_{\mathrm{N}-\mathrm{mEPR}} * \mathrm{X}_{\mathrm{N}},
$$

The end point line that passes beyond the most recent point $(X Y)$ and equation (2) can be rewritten by using the position $\left(Y_{N}\right.$ and the elapsed time $\left(X-X_{N}\right)$ as (5):

$$
B_{E P R}=Y_{n-m E P R} *\left(X-X_{n}\right),
$$

\subsubsection{EPR Forecast and Visualization}

For the graphical representation of the EPR forecast of EPR4Q, it is applied the v.to.points tool in the vector lines of transects results to get the values of EPR and to allow the application of the next tools (Figure 4a,b). The Rectangles, Ovals, and Diamonds tool create a rectangle, ellipse or diamond polygon from the input point layer using the specified width, height and rotation value [57]. The diamond polygons express the EPR forecast properly as the height value of the diamond. The value of the width parameter is the spacing parameter of v.to.points defined by the user at the beginning (Figure 3b), and the rotation parameter is filled with the beach angle specified in the model GUI (Graphical User Interface) (Figure $4 b$ ).

To extract each side of the EPR forecast (advance and retreat movement), the location of the baseline is shifted with a high distance $(2 \mathrm{~km})$ with the v.parallel tool, which creates a parallel line from input vector lines [68]. After, the AOSB method is applied to cover and extract the area of diamond shapes with EPR result (Figure 4c). With the Union tool that allows unified vector layers, the buffers from the parallel baseline and the divided buffer of the newest line (created at the beginning of the model construction) are united (Figure 4d). This procedure generates a polygon with the shape of the parallel buffer and the buffer of the newest shoreline, which extracts the positive and negatives values of EPR results (Figure 4e). The last process applies the color ramps by the Set Style for Vector Layer tool (Figure 4f), which administers the style to a layer importing a QML file [57]. The output of this procedure is represented in Section 4 in Figure 5. 


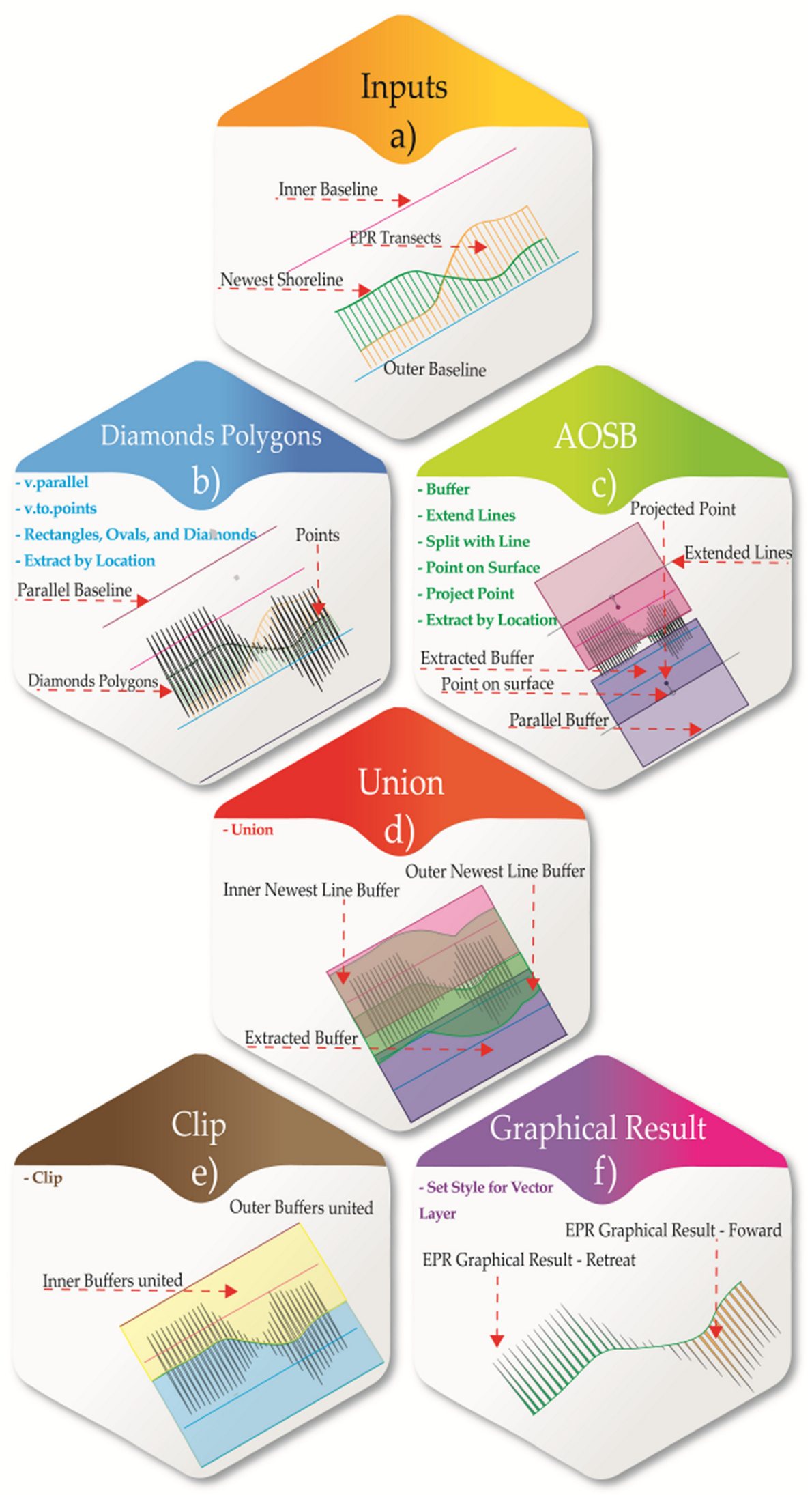

Figure 4. Graphical visualization process of EPR4Q tool: (a) inputs (inner and outer baseline, EPR transects, and shorelines); (b) diamond polygons (v.parallel tool, v.to.points tool, and Extract by Location tool); (c) alternative one-side buffer (Buffer tool, Extend Lines tool, Split with Line tool, Point on Surface tool, Project Point tool, and Extract by Location tool); (d) union; (e) clip; (f) graphical result (Set Style for Vector Layer tool). 

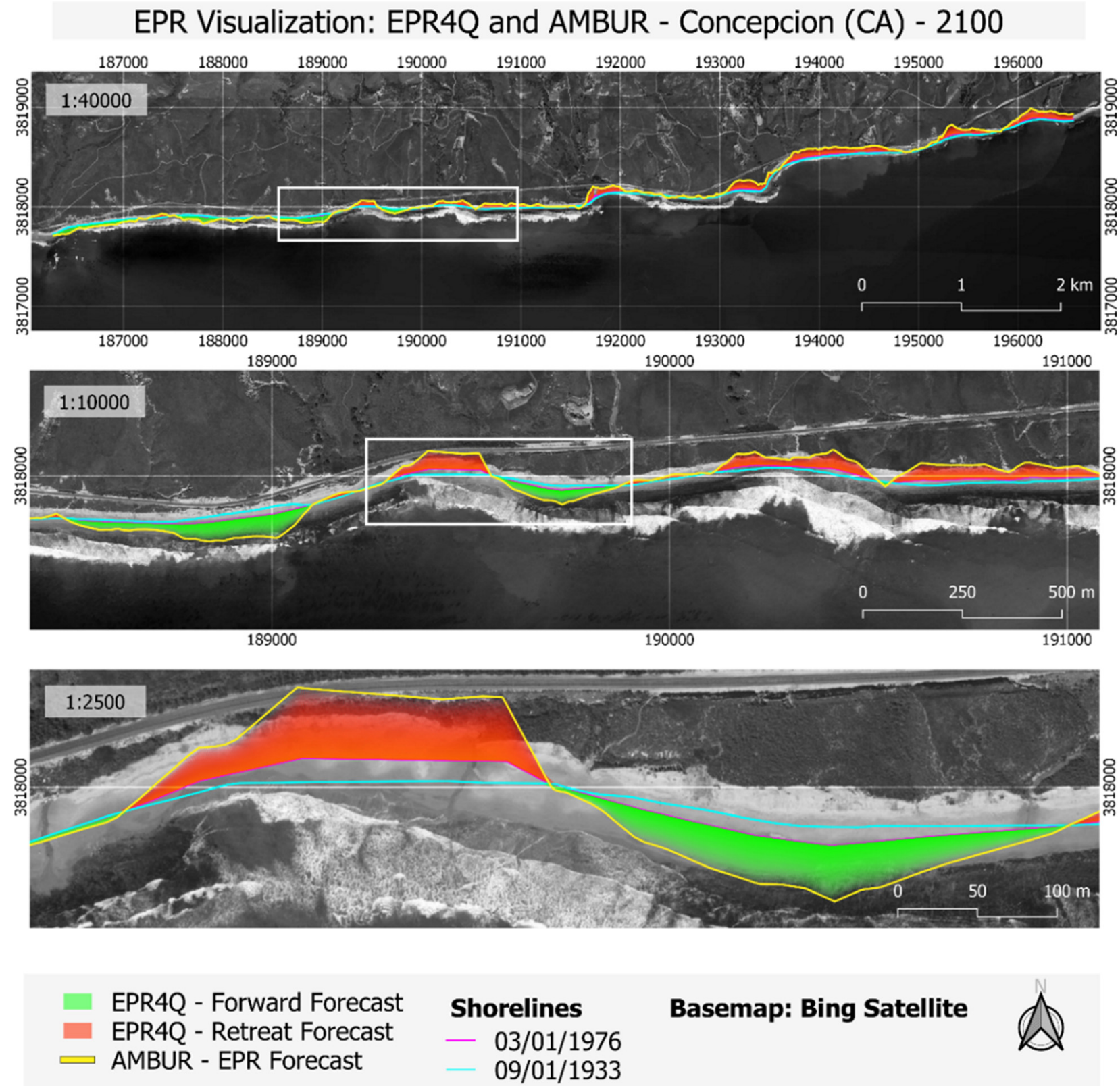

Basemap: Bing Satellite

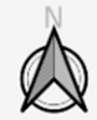

Figure 5. Visualization of EPR forecast of EPR4Q and Analyzing Moving Boundaries Using R (AMBUR) tools for 2100 in Concepcion, CA.

\subsection{Validation Process}

\subsubsection{Shorelines Data}

The Hampton and Rockport shoreline vectors have a total shoreline position uncertainty of 5.5 meters [63], and the total shoreline position uncertainty for Concepcion and Arlight is 10.1 meters [62], both, including the root mean square errors (RMSE) of georeferencing and digitizing air photo, and uncertainty of the high water line.

The shoreline analysis with AMBUR (version 1.1.27), DSAS (version 5.0), and EPR4Q (version 1.0) is applied in two types of shorelines: indented or nonlinear (i.e., with irregular morphology) and linear. Furthermore, the analysis includes extensive $(>1 \mathrm{~km})$ and nonextensive $(\leq 1 \mathrm{~km})$ coastal stretches. Finally, the shoreline orientation is also assessed to reproduce how the EPR4Q can result in different places in the world (i.e., shoreline with the ocean in the south, north, east and west) (Table 1). 


\subsubsection{Transects Selection and Statistical Analysis}

The transects with a land (inner) and ocean (outer) baseline and a spacing of $1.0 \mathrm{~m}$ are considered in the three tools. The baselines are rectilinear and parallel to the shorelines to reduce the noises and bias in transects of sinuous baselines. The perpendicular transects of AMBUR and DSAS are smoothed with the default values suggested by the models (i.e., DSAS - smoothing distance: $500 \mathrm{~m}$; AMBUR—window size: 5) because the selection of better transect induces a bias in analysis when favoring the model that reaches the best filtering result. Otherwise, not using a filter process can prejudice the tools that allow a filter process. To balance this it is chosen the default values of smooth distance (DSAS), and windows size (AMBUR) since the results of default parameters seem adequate.

The AMBUR transects are selected in QGIS to use as a reference and thus, to allow the statistical analysis between AMBUR, EPR4Q, and DSAS results. A shapefile is created with one unique attribute table, including the three EPR results with the same identification (ID). For this, a polygon buffer is created in AMBUR transects with a width of $0.6 \mathrm{~m}$ and the same attribute table of transects (AMBUR results). The value $0.6 \mathrm{~m}$ is chosen to reach $0.3 \mathrm{~m}$ of each side of AMBUR transects and select transects near this area and not cross the area of the surrounding transects. Next, the consecutive first matching transects of DSAS and EPR4Q that show some spatial criteria (intersects, overlaps, contains, within, equals, crosses, and touches) associated with the buffer created in AMBUR are selected. This method also avoids the problem of comparing distinct transects, only analyzing transects close to the reference (AMBUR transects).

The attribute table containing the EPR results of AMBUR, EPR4Q, and DSAS is extracted in order to analyze basic statistics parameters (mean, standard deviation, median, maximum, minimum) and to obtain matrix correlation using Pearson's coefficient. These analyses are performed in $\mathrm{R}$ language (version 3.5.0) by running the libraries Pastec (version 1.3.21) and PerformanceAnalytics (version 2.04), respectively.

\section{Results}

The tools AMBUR, EPR4Q, and DSAS, were performed successfully in all beaches of the study area, with a positive correlation between the tools. Furthermore, only AMBUR and EPR4Q have forecast visualization for the EPR method. Figure 5 serves as an example to demonstrate the result of the EPR4Q method visualization.

The result reveals the notable visual similarity with AMBUR when predicting the Concepcion (CA) shoreline for 2100. The value of beach angle defined for the example in Figure 5 was $90^{\circ}$.

\subsection{Linear/Extensive/Ocean to the South-Concepcion (CA)}

Concepcion shoreline is an example of an extensive (11 km length) and linear shoreline. The Pearson's correlation coefficient between the three models reached the maximum value (1.00), showing that all the models present similar values. In the frequency curve, it is possible to observe the identical pattern of the distribution (Figure 6). 


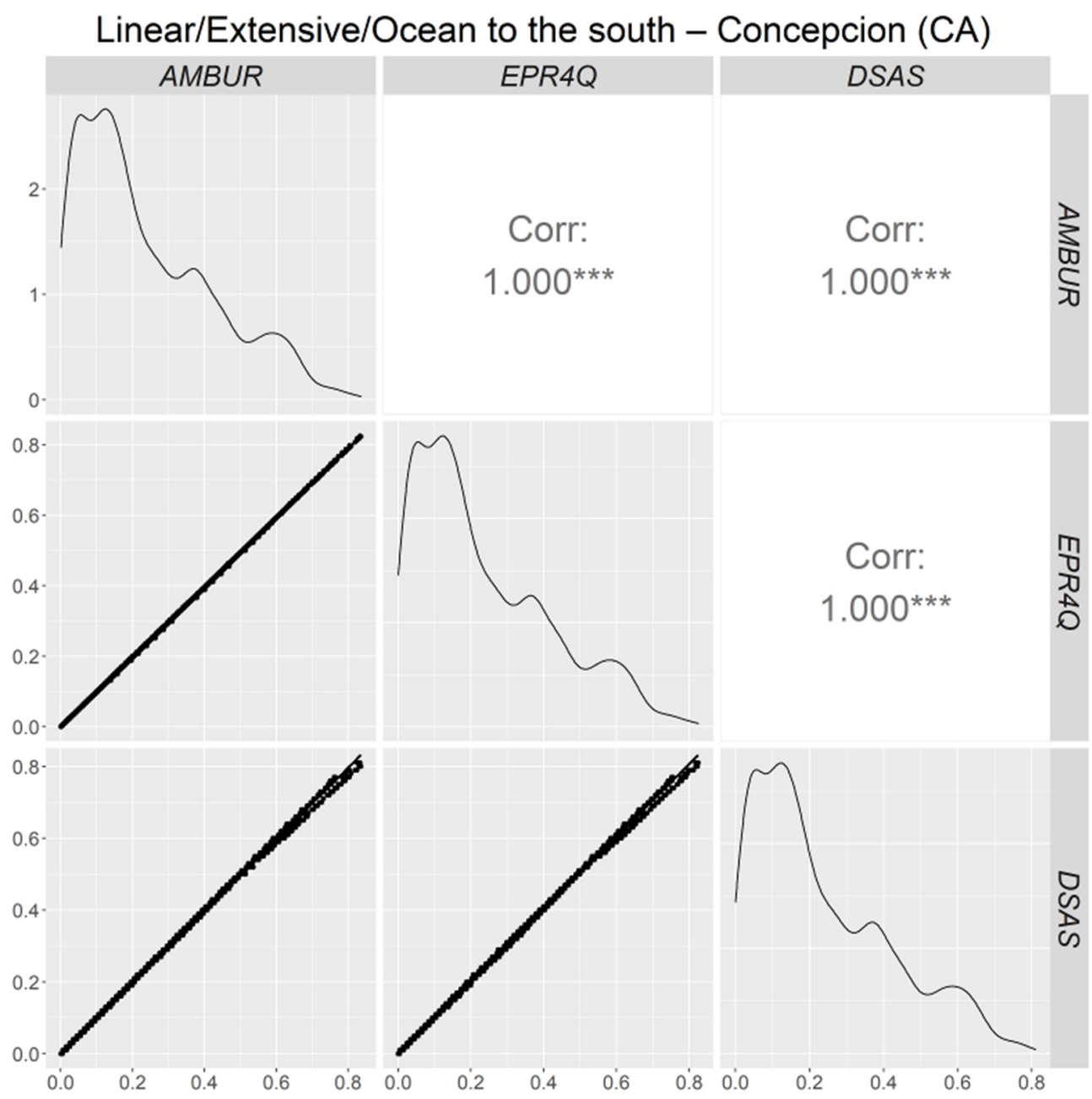

Figure 6. Matrix correlation of AMBUR, EPR4Q, and digital shoreline analysis system (DSAS) models on Linear/Extensive/Ocean to the south for Concepcion coast. $p$-value significance symbols: " $* * * *-0.001 ; “ * * *-0.01 ; “ *$ " -0.05 ; "." - 0.1 ; No symbol - 1 . The matrix correlation shows the scatter plot between the models $($ EPR $4 Q \times$ DSAS, EPR4Q $\times$ AMBUR, AMBUR $\times$ DSAS) on the left side. The frequency curve of the histogram of each model on diagonal and Pearson's correlation is presented on the right.

Figure 7 shows the results according to AMBUR, EPR4Q, and DSAS tools; it is difficult to distinguish the differences between transects due to the extreme similarity. In this example, the models seem to provide suitable results in linear and extensive shorelines. All the models equally recognized the areas of accretion and erosion, and the shoreline orientation did not affect the results. 


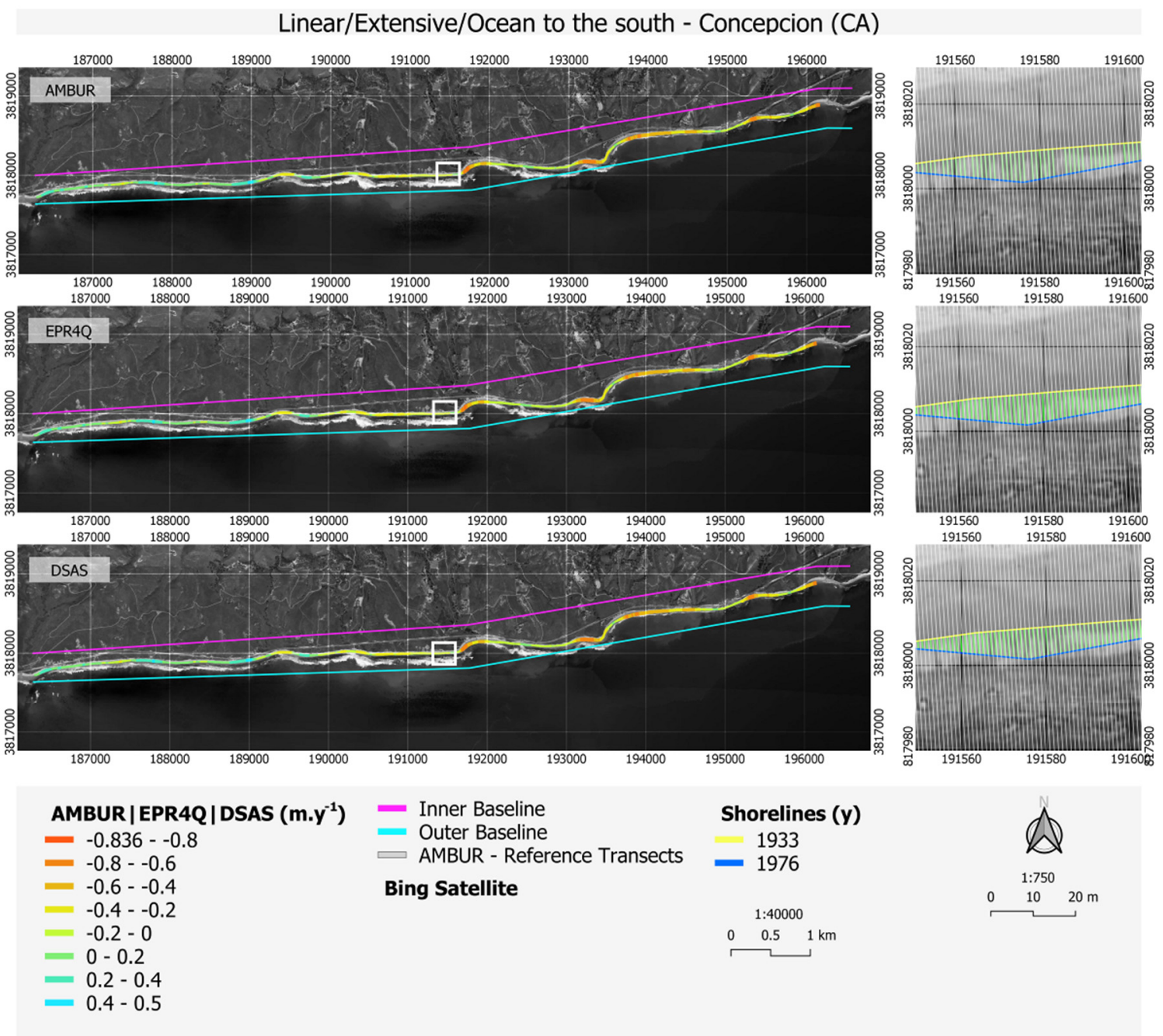

Figure 7. Shoreline changes in Concepcion using the AMBUR, EPR4Q and DSAS tools. White box shows the detail of transects with the reference transect (AMBUR unfiltered transects).

The values of statistical parameters are quite similar for the three tools (Table 2). The results revealed a retreat of the shoreline between 1976 and 1993, with a mean value of $-0.12 \mathrm{~m} \cdot \mathrm{y}^{-1}$ and a median value of -0.08 or $-0.09 \mathrm{~m} \cdot \mathrm{y}^{-1}$ depending on the model used. The identical mean (Table 2) and the frequency curve of the histogram (Figure 6) are a good indicator that the results are uniform for all models. The highest retreat rates $\left(-0.84 \mathrm{~m} \cdot \mathrm{y}^{-1}\right)$ were observed on the west side, and the highest advance rates $\left(0.48 \mathrm{~m} \cdot \mathrm{y}^{-1}\right)$ were reported on the northeast of the map (Figure 7).

Table 2. Statistical parameters between the different tools applied to the Concepcion shoreline.

\begin{tabular}{cccc}
\hline Parameter & AMBUR & EPR4Q & DSAS \\
\hline Minimum $\left(\mathrm{m} \cdot \mathrm{y}^{-1}\right)$ & -0.84 & -0.82 & -0.81 \\
Maximum $\left(\mathrm{m} \cdot \mathrm{y}^{-1}\right)$ & 0.47 & 0.47 & 0.48 \\
Mean $\left(\mathrm{m} \cdot \mathrm{y}^{-1}\right)$ & -0.12 & -0.12 & -0.12 \\
Median $\left(\mathrm{m} \cdot \mathrm{y}^{-1}\right)$ & -0.08 & -0.09 & -0.08 \\
Standard deviation $\left(\mathrm{m} \cdot \mathrm{y}^{-1}\right)$ & 0.25 & 0.25 & 0.26 \\
\hline
\end{tabular}

\subsection{Nonlinear/Extensive/Ocean to the West-Arlight (CA)}

The Arlight (CA) coast is characterized by an extensive shoreline of about $4 \mathrm{~km}$ in length, an irregular outline, and the continent is set on the east side (Figure 1). The 
correlation matrix showed high Pearson's correlation coefficients between EPR4Q and AMBUR (0.946) and EPR4Q and DSAS (0.940). However, the AMBUR and DSAS calculation methods revealed the highest similarity with a correlation coefficient of 0.995 (Figure 8).

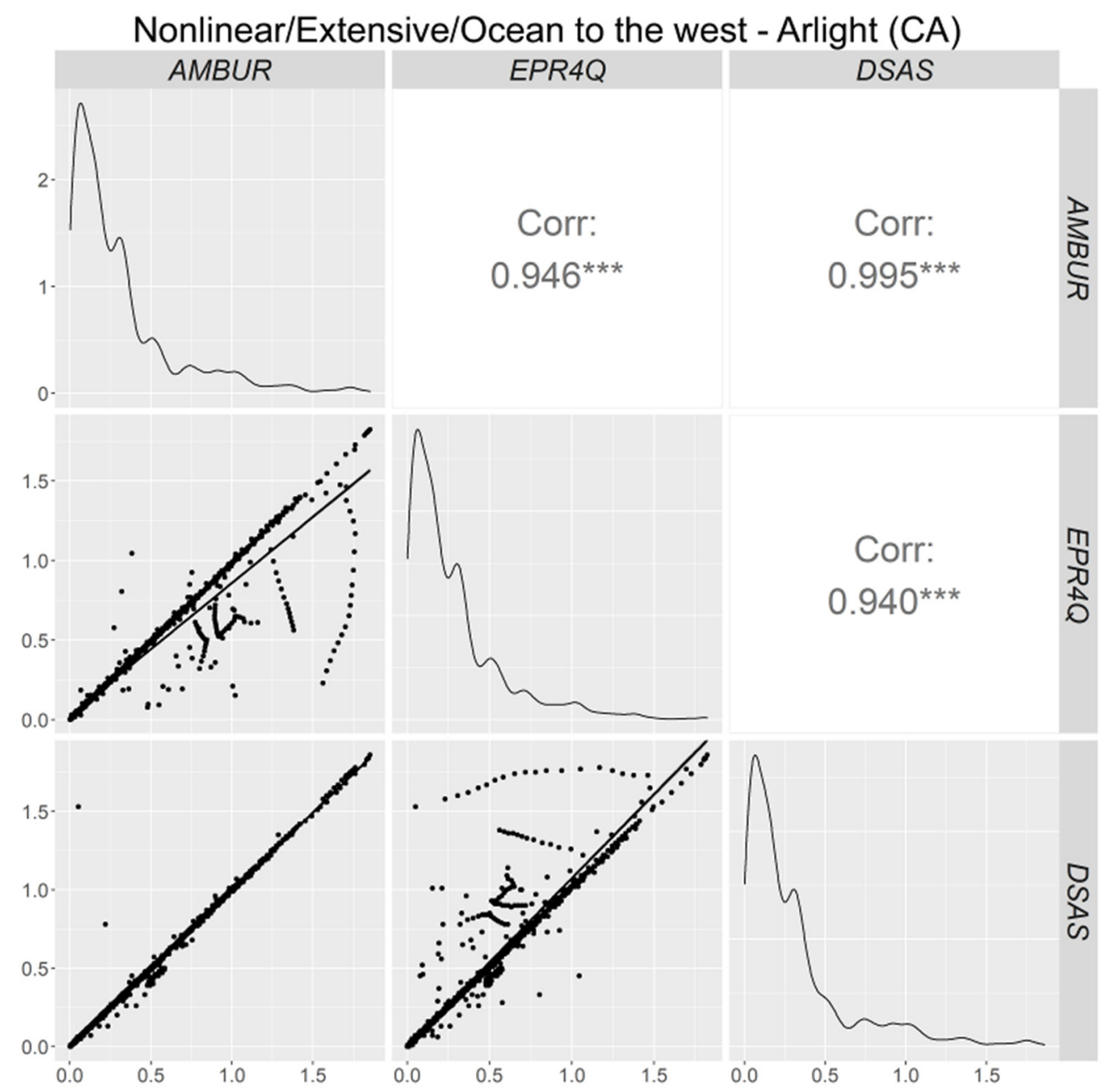

Figure 8. Matrix correlation of AMBUR, EPR4Q, and DSAS models on Indented/Extensive/Ocean to the west for Arlight coast. $p$-value significance symbols: “***”-0.001; “**”- -0.01 ; “*” -0.05 ; "." -0.1 ; No symbol-1. The matrix correlation shows the scatter plot between the models $(E P R 4 Q \times$ DSAS, EPR4Q $\times$ AMBUR, AMBUR $\times$ DSAS) on the left side. The frequency curve of the histogram of each model on diagonal and Pearson's correlation is presented on the right.

In linear stretches, observed in the center and in the extreme north of the sector, it can be observed similarities between the outcomes. Nevertheless, there are some differences between models in the stretches with an embayment configuration (Figure 9-white box). 


\section{Nonlinear/Extensive/Ocean to the west - Arlight (CA)}
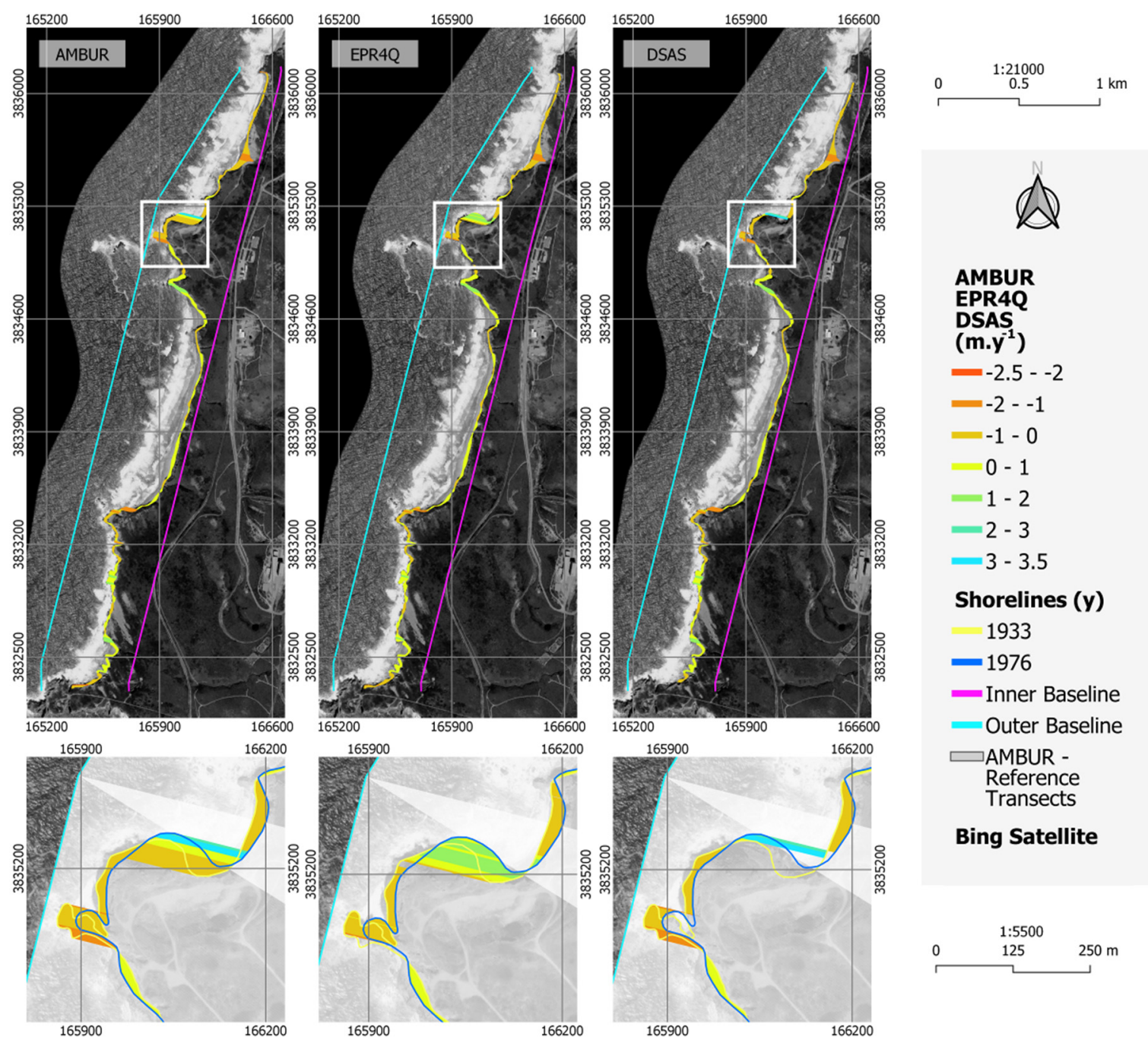

Shorelines (y)

1933

$-1976$

- Inner Baseline

- Outer Baseline

$\square$ AMBUR -

Reference

Transects

Bing Satellite

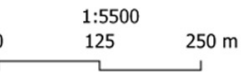

Figure 9. Shoreline changes in Arlight coast using the AMBUR, EPR4Q and DSAS tools. White box shows the details of transects in embayment configuration.

The statistical analysis applied to the Arlight coast explains the differences detected in the results. The AMBUR minimum value $\left(-2.11 \mathrm{~m} \cdot \mathrm{y}^{-1}\right)$ shows significant alteration when compared with the other models $\left(-1.82 \mathrm{~m} \cdot \mathrm{y}^{-1}\right.$ and $\left.-1.86 \mathrm{~m} \cdot \mathrm{y}^{-1}\right)$. The maximum value of AMBUR $\left(3.3 \mathrm{~m} \cdot \mathrm{y}^{-1}\right)$ is comparable with the DSAS method but very different from that obtained with EPR4Q $\left(1.6 \mathrm{~m} \cdot \mathrm{y}^{-1}\right.$ ) (Table 3). However, the median (from $-0.03 \mathrm{~m} \cdot \mathrm{y}^{-1}$ to $-0.01 \mathrm{~m} \cdot \mathrm{y}^{-1}$ ) and mean (from $0 \mathrm{~m} \cdot \mathrm{y}^{-1}$ to $0.01 \mathrm{~m} \cdot \mathrm{y}^{-1}$ ) values found with the three methods are quite similar.

Table 3. Statistical parameters between the different tools applied to the Arlight shoreline.

\begin{tabular}{cccc}
\hline Parameter & AMBUR & EPR4Q & DSAS \\
\hline Minimum $\left(\mathrm{m} \cdot \mathrm{y}^{-1}\right)$ & -2.11 & -1.82 & -1.86 \\
Maximum $\left(\mathrm{m} \cdot \mathrm{y}^{-1}\right)$ & 3.3 & 1.6 & 3.3 \\
Mean $\left(\mathrm{m} \cdot \mathrm{y}^{-1}\right)$ & 0 & 0 & 0.01 \\
Median $\left(\mathrm{m} \cdot \mathrm{y}^{-1}\right)$ & -0.03 & -0.03 & -0.01 \\
Standard deviation $\left(\mathrm{m} \cdot \mathrm{y}^{-1}\right)$ & 0.47 & 0.40 & 0.46 \\
\hline
\end{tabular}




\subsection{Linear/Non-Extensive/Ocean to the East-Hampton (NH)}

In the example of linear, non-extensive, and the ocean to the east shoreline, the EPR analysis of the tools revealed a high correlation coefficient (0.998) between EPR4Q and AMBUR and 0.980 between EPR4Q and DSAS (Figure 10).

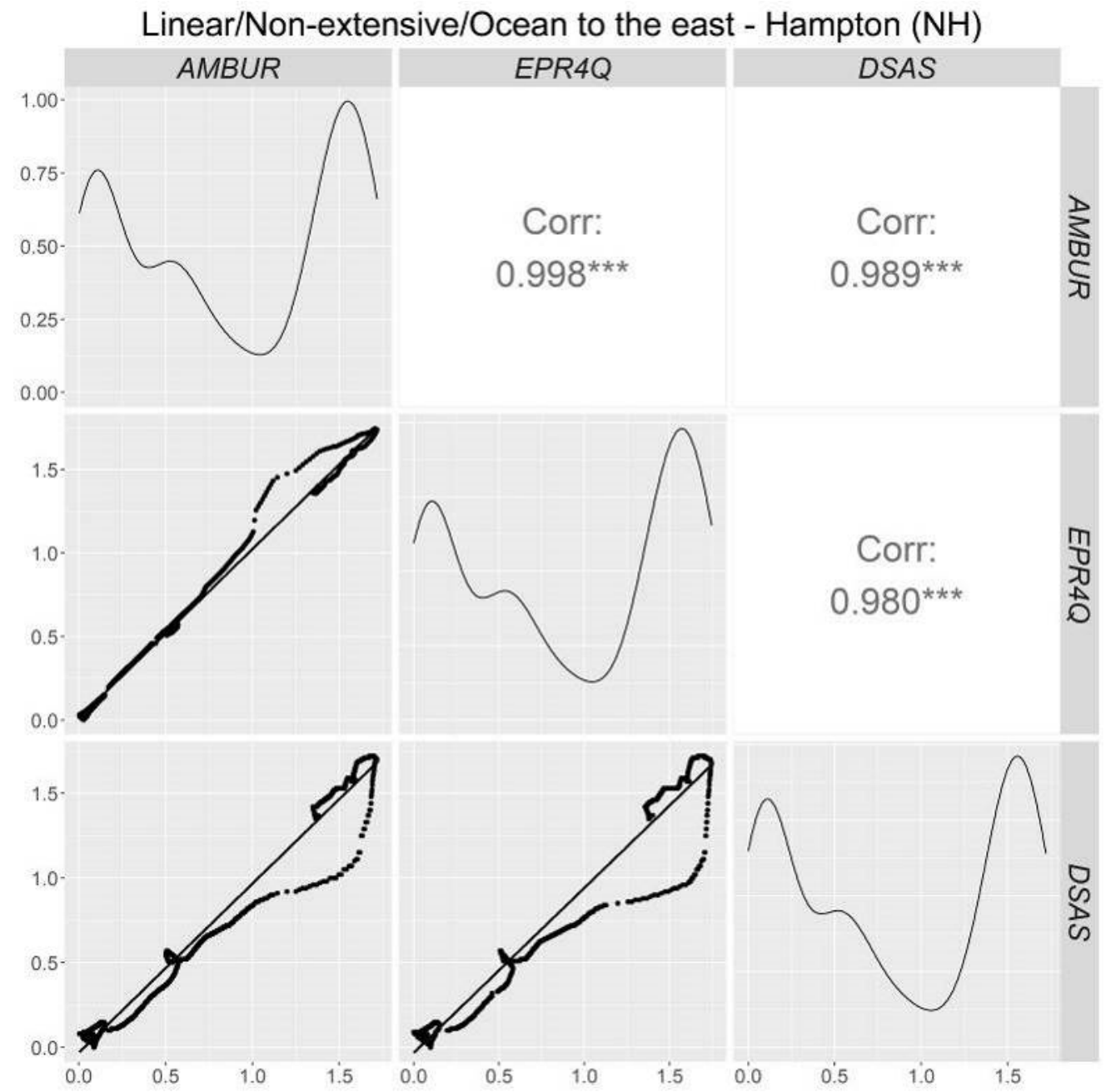

Figure 10. Matrix correlation of AMBUR, EPR4Q, and DSAS models on Linear/Non-extensive/Ocean to the east for Hampton coast. $p$-value significance symbols: “***”- 0.001 ; “**”- -0.01 ; “*”-0.05; "." -0.1 ; No symbol -1 . The matrix correlation shows the scatter plot between the models $(E P R 4 Q \times$ DSAS, EPR4Q $\times$ AMBUR, AMBUR $\times$ DSAS) on the left side. The frequency curve of the histogram of each model on diagonal and Pearson's correlation is presented on the right.

The results show a displacement in the DSAS transects of 23 meters when compared with AMBUR and EPR4Q results. It is also possible to see a difference in the angle $\left(7^{\circ}\right)$ of transects on EPR4Q in comparison with the reference transects (AMBUR) (Figure 11—white box). 
Linear/Non-extensive/Ocean to the east - Hampton (NH)
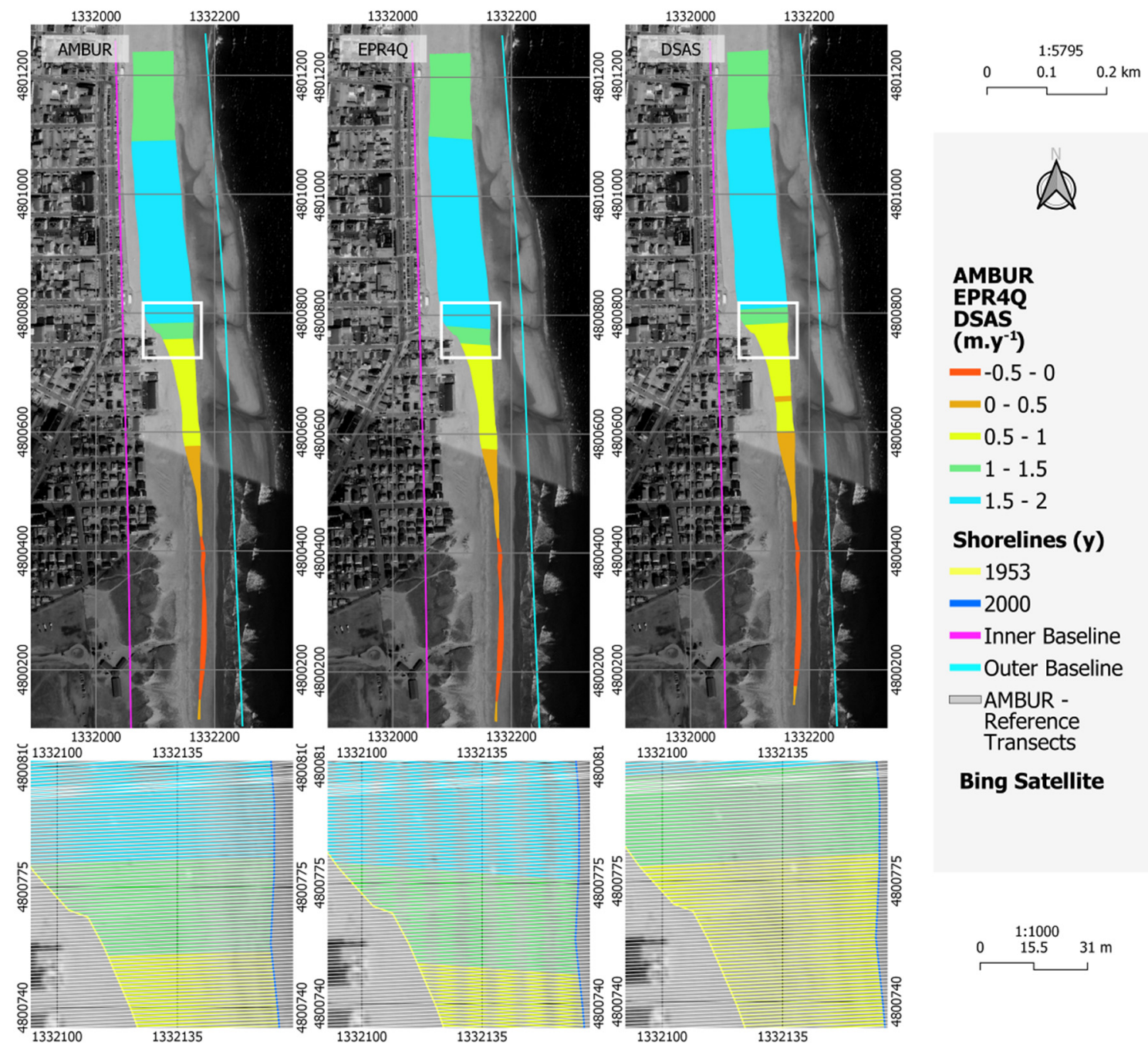

\section{Bing Satellite}

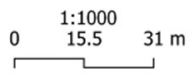

Figure 11. Shoreline changes in Hampton using the AMBUR, EPR4Q, and DSAS tools. White box shows in detail the tools results with the reference transects (AMBUR no filtered transects).

Basic statistics applied to AMBUR and DSAS results show the same values (Table 4). Regarding EPR4Q, the values are quite similar to those obtained with the other models. The mean shoreline retreat was about $-0.76 /-0.78 \mathrm{~m} \cdot \mathrm{y}^{-1}$ between 1953 and 2000, depending on the model considered.

Table 4. Statistical parameters between the different methods applied to the Hampton shoreline.

\begin{tabular}{cccc}
\hline Parameter & AMBUR & EPR4Q & DSAS \\
\hline Minimum $\left(\mathrm{m} \cdot \mathrm{y}^{-1}\right)$ & -0.15 & -0.15 & -0.15 \\
Maximum $\left(\mathrm{m} \cdot \mathrm{y}^{-1}\right)$ & 1.72 & 1.73 & 1.72 \\
Mean $\left(\mathrm{m} \cdot \mathrm{y}^{-1}\right)$ & 0.76 & 0.78 & 0.76 \\
Median $\left(\mathrm{m} \cdot \mathrm{y}^{-1}\right)$ & 0.62 & 0.58 & 0.62 \\
Standard deviation $\left(\mathrm{m} \cdot \mathrm{y}^{-1}\right)$ & 0.71 & 0.71 & 0.71 \\
\hline
\end{tabular}

\subsection{Nonlinear/Non-Extensive/Ocean to the North-Rockport (MA)}

The shoreline of Rockport is irregular and less than $1 \mathrm{~km}$ in length; the ocean is situated to the north. This case presents a weak correlation coefficient of DSAS when 
comparing with AMBUR (correlation coefficient = 0.116) and EPR4Q (correlation coefficient $=0.149$ ) (Figure 12).

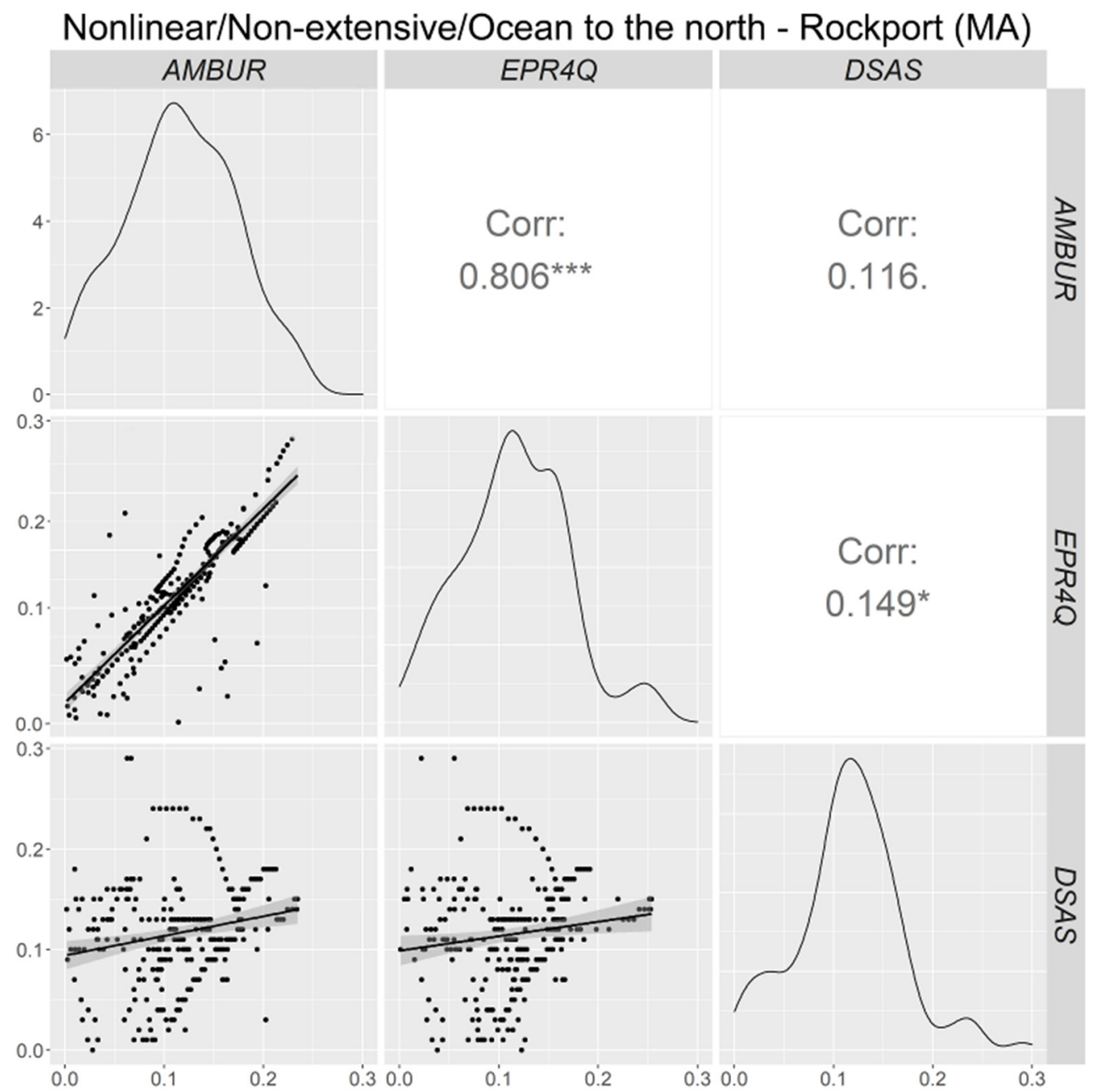

Figure 12. Matrix correlation of AMBUR, EPR4Q, and DSAS models on on Nonlinear/Non-extensive/Ocean to the north for Rockport coast. $p$-value significance symbols: “***”- 0.001 ; “**”- -0.01 ; “*”- -0.05 ; "." -0.1 ; No symbol-1. The matrix correlation shows the scatter plot between the models $(E P R 4 Q \times$ DSAS, EPR4Q $\times$ AMBUR, AMBUR $\times$ DSAS) on the left side. The frequency curve of the histogram of each model on diagonal and Pearson's correlation is presented on the right.

The angle of DSAS transects a deviation of about $5^{\circ}$ when compared with the reference transects (AMBUR), which may be a reason for the low-performance of the correlation coefficients. Additionally, all models have different results when the indentation of the embayment is more irregular (white rectangle in Figure 13). 


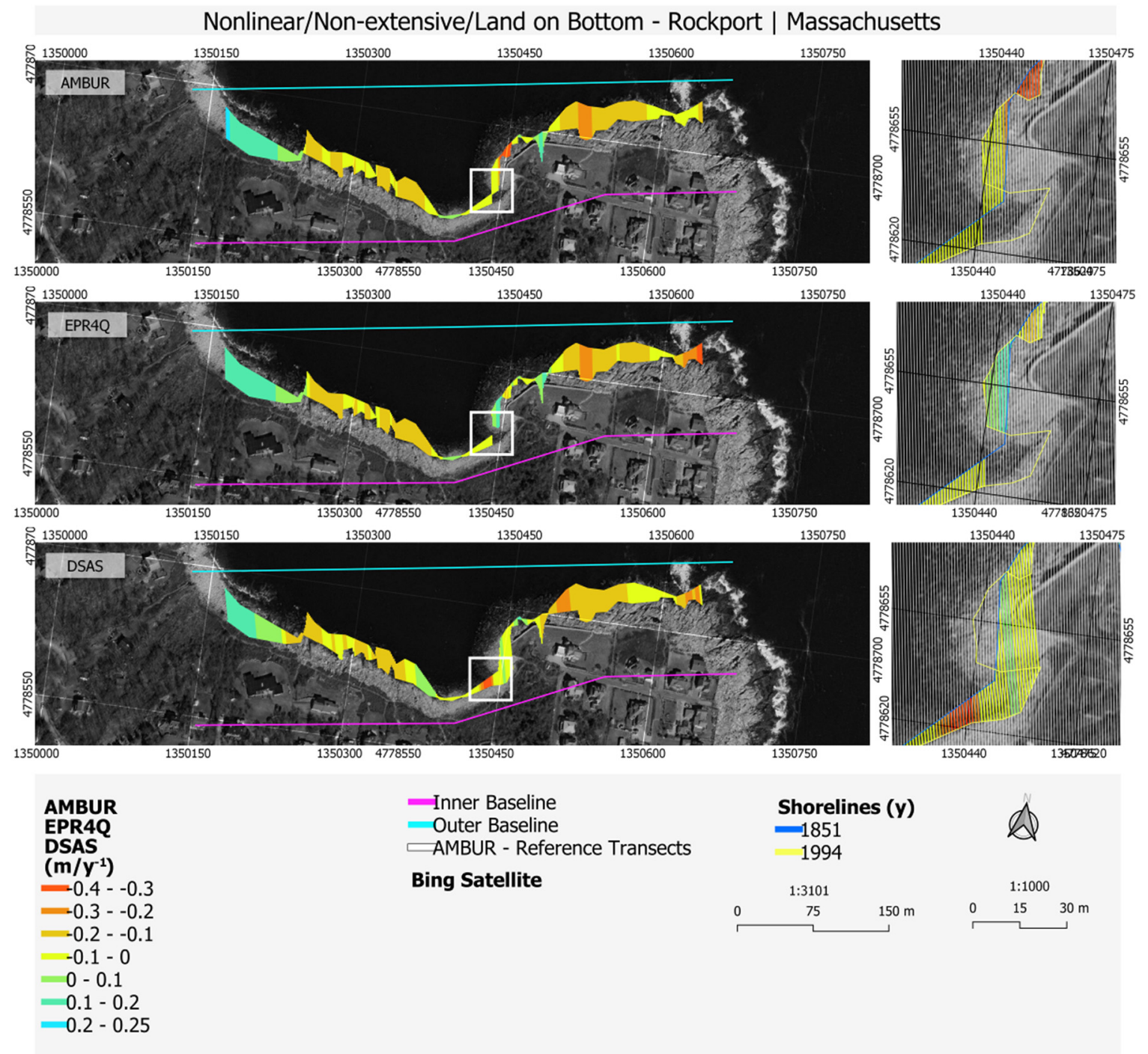

Figure 13. Shoreline changes in Rockport using the AMBUR, EPR4Q, and DSAS tools. White box shows in detail the tools results with the reference transects (AMBUR no filtered transects).

The statistical parameters indicate a similar standard deviation for all models (Table 5). The maximum values obtained with AMBUR and EPR4Q models are analogous, whereas those obtained with DSAS are twice the maximum value found with EPR4Q. The mean value of -0.07 or $0.05 \mathrm{~m} \cdot \mathrm{y}^{-1}$ depending on the model, suggest slight changes in shoreline position in 1994. The maximum changes in the shoreline position were observed in the areas more exposed to waves and the minimum in the embayed coast.

Table 5. Statistical parameters between the different methods applied to the Rockport shoreline analysis.

\begin{tabular}{cccc}
\hline Parameter & AMBUR & EPR4Q & DSAS \\
\hline Minimum $\left(\mathrm{m} \cdot \mathrm{y}^{-1}\right)$ & -0.21 & -0.19 & -0.32 \\
Maximum $\left(\mathrm{m} \cdot \mathrm{y}^{-1}\right)$ & 0.35 & 0.38 & 0.19 \\
Mean $\left(\mathrm{m} \cdot \mathrm{y}^{-1}\right)$ & 0.05 & 0.07 & -0.07 \\
Median $\left(\mathrm{m} \cdot \mathrm{y}^{-1}\right)$ & 0.07 & 0.09 & -0.08 \\
Standard deviation $\left(\mathrm{m} \cdot \mathrm{y}^{-1}\right)$ & 0.11 & 0.1 & 0.1 \\
\hline
\end{tabular}




\section{Discussion}

The results obtained in the coastal areas with linear shorelines showed the highest correlation coefficients, while irregular and embayed shorelines displayed the lowest values. This reveals that AMBUR, EPR4Q, and DSAS could not produce suitably transects for indented (nonlinear) shorelines considering the scale used in the study cases (transects with $1.0 \mathrm{~m}$ spacing) and the shape of the baselines (rectilinear). The problems with transects in embayed shorelines had already been reported by [50], who suggested the use of "near" and "filtered" transect methods to adjust transects to curved shoreline segments. Nevertheless, the authors recognize that these solutions may not be enough in highly irregular shorelines. Researchers [69] proposed the smoothing distance to avoid transect intersection in the case of DSAS methodology. They also recommended that the distance should be longer than the width of the bends in the shoreline, but they advise that using high smoothing values originate transects that are overly smoothed and undesirably oriented parallel or nearly parallel to the baseline. However, [70] affirm that transects can be representative of a coastal sector, but their position does not necessarily fall in the most representative point of it, especially when the shoreline is not linear.

The transects are, according to [70], generally defined keeping in mind the scale of the project and the spatial resolution used. Due to this, the errors in irregular shorelines are probably related to the wrong scale in relation to the spatial resolution of the USGS shoreline. In addition, tests using the same transects in the three tools (DSAS, AMBUR and EPR4Q) resulted in identical results. This proves that the EPR calculation process with the field calculator tool of EPR4Q works properly.

In the literature, there are several studies that do not show the transects associated with the shoreline analysis (i.e., $[42,53,56]$ ) or when included; it is possible to identify some errors in orientation (i.e., $[40,45,46])$. In addition, the EPR4Q $\left(7^{\circ}\right.$ in Figure 11$)$ and DSAS ( $5^{\circ}$ in Figure 13) showed transects with wrong orientations comparing with the reference transects (AMBUR). These errors are related to the baselines, and when this happens, it requires the creation of new ones with different configurations and settings. The transects were not corrected in this study to evaluate the automatic creation of transects in the first try and also to avoid bias selecting better transects to the others. In this work, the tools were compared using 1.0 meters of distance between transects and rectilinear baselines. For the aforementioned reasons, the use of other baselines shapes and transects distance need to be evaluated in future studies.

The visualization method (EPR forecast-example in Figure 5) is still experimental. Therefore, although the EPR forecast value found in the attribute table of shapefile is correct, the graphical visualization may not be the correct one. For this reason, it is important to make sure that the diamond shapes are well created. The visualization problem can be solved by trying different baseline shapes for the clipping process (Figure 4e) or editing the vector layer and excluding the wrong generated forecast diamond shapes. This problem will be fixed in future EPR4Q versions.

In the EPR4Q tool, some steps can be reconsidered with new versions of QGIS in response to tool updates and improvements on the graphical modeler. For example, the process of diamond shape went through a long process so it could be split with the newest shoreline, and it is not difficult to contemplate other theoretical easier solutions.

However, the advantage of the EPR4Q tool, in addition to being designed for opensource software, is the facility to obtain EPR results in a few minutes, without the necessity to switch software, analyze baseline orientations or create complex databases as it happens in DSAS and AMBUR tools. It was noticed that the EPR4Q is two (DSAS) and three times (AMBUR) faster, tested with Microsoft Surface Laptop 3-Intel(R) Core (TM) i5-1035G7, CPU 1.50 GHz, 8.00 GB RAM, and SSD Disk.

Finally, it is important to highlight that the low-code platforms (i.e., QGIS graphical modeler) are a recent technology with limitations. Because of this, it is not possible to fully compare with the capability of traditional hand-coded computer programming; otherwise, the potential of this technology is promising. 


\section{Conclusions}

Although the tools used in this study have their advantage and limitations for calculating the shoreline movement, the EPR4Q model, created in QGIS, returns acceptable results with similar values, such as AMBUR and DSAS software. The results of EPR4Q underscore high statistical correlation coefficients of 0.98 and 1.00 on linear, extensive, and non-extensive shorelines. Regarding embayed shorelines, the EPR4Q, as well the AMBUR and DSAS, needs attention to create specific transects and thus, to improve the obtained results. It is important to keep in mind that the first test using identical transects drove the same results in the three tools. This indicates that EPR4Q analyzes the transects with the same method as the other tools. Therefore, the unique difference between EPR4Q, AMBUR and DSAS is the process of transects creation. This work constitutes a first step towards the creation of a tool that, since it is free and open-source, can be edited for the scientific community for different purposes, such as adding more prediction analysis or rebuild in a plugin. It is remarkable the potential of QGIS and graphical modeler to create functional tools. On the other hand, it was necessary several tool adaptations (i.e., alternative one-side buffer) to reach the results due to the limitations of the graphical modeler that increased the complexity of the EPR4Q.

To sum up, the main advantages of the EPR4Q are: (a) the complete open-source nature of the tool; (b) easier to implement than the other complete open-source tool AMBUR; (c) potential quicker run-time; and d) no need to switch between software as with the case of QGIS and AMBUR.

Studies that consider the comparative approach between methods are of great importance for coastal managers, given that many coastal cities show serious problems related to the action of extreme events or sea-level rise. Finally, the EPR4Q tool is freely available to download (10.5281/zenodo.4511400), and it is accompanied by the guidelines to reproduce the analysis in different locations of the world.

Author Contributions: Conceptualization, Lucas Terres de Lima; formal analysis, Sandra FernándezFernández; methodology, Lucas Terres de Lima and Cristina Bernardes; software, Lucas Terres de Lima; supervision, Sandra Fernández-Fernández and Cristina Bernardes; validation, Lucas Terres de Lima, Jean Marcel de Almeida Espinoza and Miguel da Guia Albuquerque; visualization, Miguel da Guia Albuquerque; writing — original draft, Lucas Terres de Lima; writing-review and editing, Sandra Fernández-Fernández, Jean Marcel de Almeida Espinoza, Miguel da Guia Albuquerque and Cristina Bernardes. All authors have read and agreed to the published version of the manuscript.

Funding: L.T Lima is grateful to the Brazilian National Council for Scientific and Technological Development (CNPq) for the CSF's (Ciência sem Fronteiras) program doctoral fellowship granted (249636/2013-1). Thanks are due to FCT/MCTES for the financial support to CESAM (UIDP/50017/2020+UIDB/50017/2020) through national funds.

Data Availability Statement: Not applicable.

Acknowledgments: The authors gratefully acknowledge anonymous reviewers for their insightful comments.

Conflicts of Interest: The authors declare no conflict of interest.

\section{References}

1. Luijendijk, A.; Hagenaars, G.; Ranasinghe, R.; Baart, F.; Donchyts, G.; Aarninkhof, S. The State of the World's Beaches. Sci. Rep. 2018, 8, 6641. [CrossRef]

2. Dritsas, S.E. The effect of sea level rise on coastal populations: The case of the Gironde (Estuaries of Gironde). Econ. Anal. Policy 2020, 66, 41-50. [CrossRef]

3. Boak, E.H.; Turner, I.L. Shoreline definition and detection: A review. J. Coast. Res. 2005, 21, 688-703. [CrossRef]

4. Crowell, M.; Leatherman, S.P.; Douglas, B. Erosion: Historical Analysis and Forecasting. In Encyclopedia of Coastal Science; Springer: Cham, Switzerland, 2018; pp. 1-7. [CrossRef]

5. Biondo, M.; Buosi, C.; Trogu, D.; Mansfield, H.; Vacchi, M.; Ibba, A.; Porta, M.; Ruju, A.; De Muro, S. Natural vs. Anthropic Influence on the Multidecadal Shoreline Changes of Mediterranean Urban Beaches: Lessons from the Gulf of Cagliari (Sardinia). Water 2020, 12, 3578. [CrossRef] 
6. Castelle, B.; Bujan, S.; Marieu, V.; Ferreira, S. 16 years of topographic surveys of rip-channelled high-energy meso-macrotidal sandy beach. Sci. Data 2020, 7, 1-9. [CrossRef]

7. Audère, M.; Robin, M. Assessment of the vulnerability of sandy coasts to erosion (short and medium term) for coastal risk mapping (Vendée, W France). Ocean Coast. Manag. 2021, 201, 105452. [CrossRef]

8. Nave, S.; Rebêlo, L. Coastline evolution of the Portuguese south eastern coast: A high-resolution approach in a 65 years time-window. J. Coast. Conserv. 2021, 25, 1-22. [CrossRef]

9. Pianca, C.; Holman, R.; Siegle, E. Shoreline variability from days to decades: Results of long-term video imaging. J. Geophys. Res. Ocean. 2015, 120, 2159-2178. [CrossRef]

10. Valentini, N.; Saponieri, A.; Molfetta, M.G.; Damiani, L. New algorithms for shoreline monitoring from coastal video systems. Earth Sci. Inform. 2017, 10, 495-506. [CrossRef]

11. Vos, K.; Harley, M.D.; Splinter, K.D.; Simmons, J.A.; Turner, I.L. Sub-annual to multi-decadal shoreline variability from publicly available satellite imagery. Coast. Eng. 2019, 150, 160-174. [CrossRef]

12. Santos, C.J.; Andriolo, U.; Ferreira, J.C. Shoreline response to a sandy nourishment in a wave-dominated coast using video monitoring. Water 2020, 12, 1632. [CrossRef]

13. Konlechner, T.M.; Kennedy, D.M.; O'Grady, J.J.; Leach, C.; Ranasinghe, R.; Carvalho, R.C.; Luijendijk, A.P.; McInnes, K.L.; Ierodiaconou, D. Mapping spatial variability in shoreline change hotspots from satellite data; a case study in southeast Australia. Estuar. Coast. Shelf Sci. 2020, 246, 107018. [CrossRef]

14. Ribas, F.; Simarro, G.; Arriaga, J.; Luque, P. Automatic Shoreline Detection from Video Images by Combining Information from Different Methods. Remote Sens. 2020, 12, 3717. [CrossRef]

15. Sánchez-García, E.; Palomar-Vázquez, J.M.; Pardo-Pascual, J.E.; Almonacid-Caballer, J.; Cabezas-Rabadán, C.; Gómez-Pujol, L. An efficient protocol for accurate and massive shoreline definition from mid-resolution satellite imagery. Coast. Eng. 2020, 160, 103732. [CrossRef]

16. Santos, C.A.G.; do Nascimento, T.V.M.; Mishra, M.; da Silva, R.M. Analysis of long- and short-term shoreline change dynamics: A study case of João Pessoa city in Brazil. Sci. Total Environ. 2021, 769, 144889. [CrossRef] [PubMed]

17. Harley, M.D.; Kinsela, M.A.; Sánchez-García, E.; Vos, K. Shoreline change mapping using crowd-sourced smartphone images. Coast. Eng. 2019, 150, 175-189. [CrossRef]

18. Ataol, M.; Kale, M.M.; Tekkanat, İ.S. Assessment of the changes in shoreline using digital shoreline analysis system: A case study of Kizılırmak Delta in northern Turkey from 1951 to 2017. Environ. Earth Sci. 2019, 78, 1-9. [CrossRef]

19. Arjasakusuma, S.; Kusuma, S.S.; Saringatin, S.; Wicaksono, P.; Mutaqin, B.W.; Rafif, R. Shoreline Dynamics in East Java Province, Indonesia, from 2000 to 2019 Using Multi-Sensor Remote Sensing Data. Land 2021, 10, 100. [CrossRef]

20. Bidorn, B.; Sok, K.; Bidon, K.; Burnett, W.C. An Analysis of the Factors Responsible for the Shoreline Retreat of the Chao Phraya Delta (Thailand). Sci. Total Environ. 2021, 769, 145253. [CrossRef]

21. Sengupta, M.; Ford, M.R.; Kench, P.S. Shoreline changes in coral reef islands of the Federated States of Micronesia since the mid-20th century. Geomorphology 2021, 377, 107584. [CrossRef]

22. Smith, S.A.; Barnard, P.L. The impacts of the 2015/2016 El Niño on California's sandy beaches. Geomorphology 2021, $377,107583$. [CrossRef]

23. Ardeshiri, A.; Swait, J.; Heagney, E.C.; Kovac, M. Willingness-to-pay for coastline protection in New South Wales: Beach preservation management and decision making. Ocean Coast. Manag. 2019, 178, 104805. [CrossRef]

24. Del Río, L.; Gracia, F.J.; Benavente, J. Shoreline change patterns in sandy coasts. A case study in SW Spain. Geomorphology 2013, 196, 252-266. [CrossRef]

25. Castelle, B.; Guillot, B.; Marieu, V.; Chaumillon, E.; Hanquiez, V.; Bujan, S.; Poppeschi, C. Spatial and temporal patterns of shoreline change of a 280-km high-energy disrupted sandy coast from 1950 to 2014: SW France. Estuar. Coast. Shelf Sci. 2018, 200, 212-223. [CrossRef]

26. Oyedotun, T.D.T.; Ruiz-Luna, A.; Navarro-Hernández, A.G. Contemporary shoreline changes and consequences at a tropical coastal domain. Geol. Ecol. Landsc. 2018, 2, 104-114. [CrossRef]

27. Armstrong, S.B.; Lazarus, E.D. Masked Shoreline Erosion at Large Spatial Scales as a Collective Effect of Beach Nourishment. Earth's Future 2019, 7, 74-84. [CrossRef]

28. $\mathrm{Xu}, \mathrm{N}$. Detecting coastline change with all available landsat data over 1986-2015: A case study for the state of Texas, USA. Atmosphere 2018, 9, 107. [CrossRef]

29. Hegde, A.V.; Akshaya, B.J. Shoreline Transformation Study of Karnataka Coast: Geospatial Approach. Aquat. Proc. 2015, 4, 151-156. [CrossRef]

30. Oppenheimer, M. Global warming and the stability of the West Antarctic ice sheet. Nature 1998, 393, 325-332. [CrossRef]

31. Hansen, J.; Sato, M.; Hearty, P.; Ruedy, R.; Kelley, M.; Masson-Delmotte, V.; Russell, G.; Tselioudis, G.; Cao, J.; Rignot, E.; et al. Ice melt, sea level rise and superstorms: Evidence from paleoclimate data, climate modeling, and modern observations that $2{ }^{\circ} \mathrm{C}$ global warming could be dangerous. Atmos. Chem. Phys. 2016, 16, 3761-3812. [CrossRef]

32. Holland, G.; Bruyère, C.L. Recent intense hurricane response to global climate change. Clim. Dyn. 2014, 42, 617-627. [CrossRef]

33. Collins, J.M.; Walsh, K. Hurricanes and Climate Change; Springer: Berlin, Germany, 2017; ISBN 9783319475943. [CrossRef]

34. Mentaschi, L.; Vousdoukas, M.I.; Voukouvalas, E.; Dosio, A.; Feyen, L. Global changes of extreme coastal wave energy fluxes triggered by intensified teleconnection patterns. Geophys. Res. Lett. 2017, 44, 2416-2426. [CrossRef] 
35. Himmelstoss, E. DSAS 4.0 Installation Instructions and User Guide. In The Digital Shoreline Analysis System (DSAS) Version 4.0-An ArcGIS Extension for Calculating Shoreline Change: U.S. Geological Survey Open-File Rep. 2008-1278; Thierler, E.R., Himmelstoss, E., Zichichi, J., Ergul, A., Eds.; US Geological Survey: Washington, DC, USA, 2009.

36. Fenster, M.S.; Dolant, R.; Elder, J.F. A New Method for Predicting Shoreline Positions from Historical Data. J. Coast. Res. 1993, 9 , 147-171.

37. Crowell, M.; Douglas, B.C.; Leatherman, S.P. On Forecasting Future U.S. Shoreline Positions: A Test of Algorithms. J. Coast. Res. 2015, 13, 1245-1255.

38. Thieler, E.R.; Danforth, W.W. Historical shoreline mapping (II): Application of the digital shoreline mapping and analysis systems (DSMS/DSAS) to shoreline change mapping in Puerto Rico. J. Coast. Res. 1994, 10, 600-620.

39. Oyedotun, T.D.T. Shoreline Geometry: DSAS as a Tool for Historical Trend Analysis. Geomorphol. Tech. $2014,3,1-12$.

40. Jabaloy-Sánchez, A.; Lobo, F.J.; Azor, A.; Martín-Rosales, W.; Pérez-Peña, J.V.; Bárcenas, P.; Macías, J.; Fernández-Salas, L.M.; Vázquez-Vílchez, M. Six thousand years of coastline evolution in the Guadalfeo deltaic system (southern Iberian Peninsula). Geomorphology 2014, 206, 374-391. [CrossRef]

41. Kermani, S.; Boutiba, M.; Guendouz, M.; Guettouche, M.S.; Khelfani, D. Detection and analysis of shoreline changes using geospatial tools and automatic computation: Case of jijelian sandy coast (East Algeria). Ocean Coast. Manag. 2016, 132, 46-58. [CrossRef]

42. Blue, B.; Kench, P.S. Multi-decadal shoreline change and beach connectivity in a high-energy sand system. N. Zeal. J. Mar. Freshw. Res. 2017, 51, 406-426. [CrossRef]

43. Benkhattab, F.Z.; Hakkou, M.; Bagdanavičiūte, I.; Mrini, A.E.; Zagaoui, H.; Rhinane, H.; Maanan, M. Spatial-temporal analysis of the shoreline change rate using automatic computation and geospatial tools along the Tetouan coast in Morocco. Nat. Hazards 2020, 104, 519-536. [CrossRef]

44. Franco-Ochoa, C.; Zambrano-Medina, Y.; Plata-Rocha, W.; Monjardín-Armenta, S.; Rodríguez-Cueto, Y.; Escudero, M.; Mendoza, E. Long-Term Analysis of Wave Climate and Shoreline Change along the Gulf of California. Appl. Sci. 2020, 10, 8719. [CrossRef]

45. Esmail, M.; Mahmod, W.E.; Fath, H. Assessment and prediction of shoreline change using multi-temporal satellite images and statistics: Case study of Damietta coast, Egypt. Appl. Ocean Res. 2019, 82, 274-282. [CrossRef]

46. Al-Zubieri, A.G.; Ghandour, I.M.; Bantan, R.A.; Basaham, A.S. Shoreline Evolution Between Al Lith and Ras Mahāsin on the Red Sea Coast, Saudi Arabia Using GIS and DSAS Techniques. J. Indian Soc. Remote Sens. 2020, 48, 1455-1470. [CrossRef]

47. Jackson, C.W. Quantitative Shoreline Change Analysis of an Inlet-Influenced Transgressive Barrier System; Figure Eight Island, North Carolina. Master's Thesis, University of North Carolina at Wilmington, Wilmington, NC, USA, 2004; 86p.

48. Hoeke, R.; Zarillo, G.; Synder, M. A GIS Based Tool for Extracting Shoreline Positions from Aerial Imagery (BeachTools). 2001. Available online: https:/ /apps.dtic.mil/sti/citations / ADA588790 (accessed on 3 January 2021).

49. Zarillo, G.A.; Kelley, J.; Larson, V. A GIS Based Tool for Extracting Shoreline Positions from Aerial Imagery (BeachTools) Revised. 2001. Available online: https:/ / apps.dtic.mil/sti/citations/ADA490237 (accessed on 3 January 2021).

50. Jackson, C.W.; Alexander, C.R.; Bush, D.M. Application of the AMBUR R package for spatio-temporal analysis of shoreline change: Jekyll Island, Georgia, USA. Comput. Geosci. 2012. [CrossRef]

51. Eulie, D.O.; Walsh, J.P.; Corbett, D.R. High-resolution analysis of shoreline change and application of balloon-based aerial photography, Albemarle-Pamlico estuarine system, North Carolina, USA. Limnol. Oceanogr. Methods 2013, 11, 151-160. [CrossRef]

52. Addo, K. Assessment of the Volta Delta Shoreline Change. J. Coast. Zone Manag. 2015, 18, 1-6. [CrossRef]

53. Wakefield, K.R. Georgia Southern Assessing Shoreline Change and Vegetation Cover Adjacent to Back-Barrier Shoreline Stabilization Structures in Georgia Estuaries. Ph.D. Thesis, Georgia Southern University, Statesboro, GA, USA, 2016.

54. Dennis, A.; Senthilnathan, L.; Machendiranathan, M.; Ranith, R. Shoreline demarcation on tirunelveli coast analysis moving boundaries using R (AMBUR) statistics. Ecol. Environ. Conserv. 2018, 24, 1174-1179.

55. Sankar, R.D.; Donoghue, J.F.; Kish, S.A. Mapping Shoreline Variability of Two Barrier Island Segments Along the Florida Coast. Estuaries Coasts 2018, 41, 2191-2211. [CrossRef]

56. Sankar, R.D.; Murray, M.S.; Wells, P. Decadal scale patterns of shoreline variability in Paulatuk, N.W.T., Canada. Polar Geogr. 2019, 42, 196-213. [CrossRef]

57. QGIS Development Team QGIS Geographic Information System. 2021. Available online: http://www.qgis.org/ (accessed on 11 March 2021).

58. Criollo, R.; Velasco, V.; Nardi, A.; Manuel de Vries, L.; Riera, C.; Scheiber, L.; Jurado, A.; Brouyère, S.; Pujades, E.; Rossetto, R.; et al. AkvaGIS: An open source tool for water quantity and quality management. Comput. Geosci. 2019, 127, 123-132. [CrossRef]

59. De Lima, L.; Sá, M.; Bernardes, C. Shoreline Analyst QGIS Python Plugin. 2017. Available online: https://zenodo.org/record/33 78016 (accessed on 3 January 2021).

60. Morton, R.A.; Miller, T.L.; Moore, L.J. National Assessment of Shoreline Change: Part 1: Historical Shoreline Change and Associated Land Loss along the U.S. Gulf of Mexico: U.S. Geological Survey Open-File Report 2004-1043; USGS: Santa Cruz, CA, USA, 2004.

61. Morton, R.A.; Miller, T.L. National Assessment of Shoreline Change: Part 2: Historical Shoreline Change and Associated Land Loss along the U.S. South East Atlantic Coast: U.S. Geological Survey Open-File Report 2005-1401; USGS: Santa Cruz, CA, USA, 2005.

62. Hapke, C.J.; Reid, D.; Richmond, B.M.; Ruggiero, P.; List, J. National Assessment of Shoreline Change: Part 3: Historical Shoreline Change and Associated Coastal Land Loss along Sandy Shorelines of the California Coast: U.S. Geological Survey Open-File Report 2006-1219; USGS: Santa Cruz, CA, USA, 2006. 
63. Himmelstoss, E.A.; Kratzmann, M.; Hapke, C.; Thieler, E.R.; List, J. The National Assessment of Shoreline Change: A GIS Compilation of Vector Shorelines and Associated Shoreline Change Data for the New England and Mid-Atlantic Coasts: U.S. Geological Survey Open-File Report 2010-1119; USGS: Reston, VA, USA, 2010.

64. Adams, P.N.; Inman, D.L.; Graham, N.E. Southern California Deep-Water Wave Climate: Characterization and Application to Coastal Processes. J. Coast. Res. 2008, 244, 1022-1035. [CrossRef]

65. Runkle, J.; Kunkel, K.; Easterling, D.; Frankson, R.; Stewart, B. New Hampshire State Climate Summary. 2017. Available online: https:/ / statesummaries.ncics.org/chapter/nh/ (accessed on 3 January 2021).

66. Woodruff, J.D.; Venti, N.; Mabee, S.; DiTroia, A.; Beach, D. Grain Size and Beach Face Slope on Paraglacial Beaches of New England, USA. EarthArXiv 2020. [CrossRef]

67. Elko, N.; Briggs, T.R.; Benedet, L.; Robertson, Q.; Thomson, G.; Webb, B.M.; Garvey, K. A century of U.S. beach nourishment. Ocean Coast. Manag. 2021, 199, 105406. [CrossRef]

68. GRASS Development Team. GRASS GIS 7.9.dev Reference Manual. Available online: https://grass.osgeo.org/grass79/manuals/ (accessed on 10 February 2021).

69. Himmelstoss, E.A.; Henderson, R.E.; Kratzmann, M.G.; Farris, A.S. Digital Shoreline Analysis System (DSAS) Version 5.0 User Guide; Open-File Rep. 2018-1179; U.S. Department of the Interior: Washington, DC, USA; USGS: Reston, VA, USA, 2018.

70. Anfuso, G.; Bowman, D.; Danese, C.; Pranzini, E. Transect based analysis versus area based analysis to quantify shoreline displacement: Spatial resolution issues. Environ. Monit. Assess. 2016, 10, 1-14. [CrossRef] 